WSRC-TR-2002-00569, REV. 0

Key Words: Americium, Curium, Am/Cm, Simulant

Retention: Permanent

\title{
DETERMINING THE CAUSE FOR LOW FLOWRATES DURING AM/CM SIMULANT TESTING IN F AREA
}

\author{
D. P. Lambert, T. B. Peters, M. E. Stallings, M. R. Poirier and S. D. Fink
}

April 29, 2003

Westinghouse Savannah River Company

Savannah River Site

Aiken, SC 29808

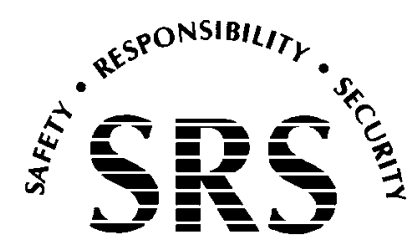

SAVANNAH RIVER SITE

Prepared for the U.S. Department of Energy Under

Contract Number DE-AC09-96SR18500 
This document was prepared in conjunction with work accomplished under Contract No. DE-AC09-96SR18500 with the U. S. Department of Energy.

\section{DISCLAIMER}

This report was prepared as an account of work sponsored by an agency of the United States Government. Neither the United States Government nor any agency thereof, nor any of their employees, makes any warranty, express or implied, or assumes any legal liability or responsibility for the accuracy, completeness, or usefulness of any information, apparatus, product or process disclosed, or represents that its use would not infringe privately owned rights. Reference herein to any specific commercial product, process or service by trade name, trademark, manufacturer, or otherwise does not necessarily constitute or imply its endorsement, recommendation, or favoring by the United States Government or any agency thereof. The views and opinions of authors expressed herein do not necessarily state or reflect those of the United States Government or any agency thereof.

This report has been reproduced directly from the best available copy.

Available for sale to the public, in paper, from: U.S. Department of Commerce, National Technical Information Service, 5285 Port Royal Road, Springfield, VA 22161, phone: (800) 553-6847, fax: (703) 605-6900

email: orders@ntis.fedworld.gov

online ordering: http://www.ntis.gov/help/index.asp

Available electronically at http://www.osti.gov/bridge

Available for a processing fee to U.S. Department of Energy and its contractors, in paper, from: U.S. Department of Energy, Office of Scientific and Technical Information, P.O. Box 62, Oak Ridge, TN 37831-0062,

phone: (865)576-8401,

fax: (865)576-5728

email: $\underline{\text { reports@ adonis.osti.gov }}$ 


\section{TABLE OF CONTENTS}

REVIEWS AND APPROVALS............................................................................................. ii

TABLE OF CONTENTS ............................................................................................................... iii

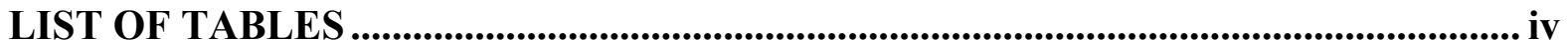

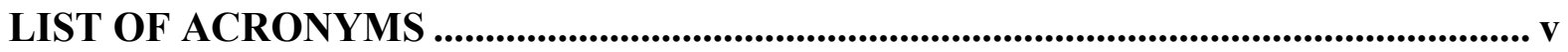

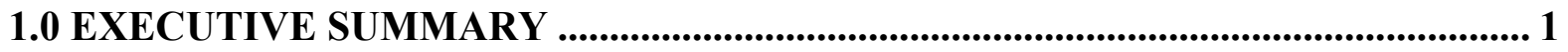

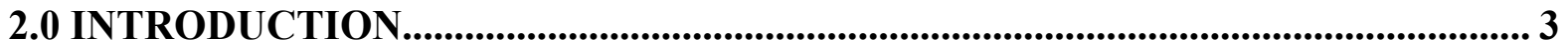

2.1. Discussion of Simulant Testing in F-Area................................................................ 4

2.1.1. Simulant Transfer \#1 (June - September 2002)............................................... 4

2.1.2. Tank Cleaning and Pipe Flushing ....................................................................... 6

2.1.3. Simulant Transfer \#2 (November - December, 2002)......................................... 6

2.1.3.1. 2000 Gallon Simulant Transfer (November 9-10, 2002) ................................. 6

2.1.3.2. 8000 Gallon Simulant Transfer (December 10, 2002) ..................................... 8

3.0 TEST REQUIREMENTS ................................................................................................ 9

4.0 EXPERIMENTAL AND ENGINEERING STUDIES ............................................... 10

4.1 Discussion of possible causes for poor flow ........................................................................ 10

4.2 Testing and Studies to Determine Cause........................................................................... 11

4.2.1 Hydraulic Calculations ......................................................................................... 11

4.2.2 Preparation of simulants and real waste............................................................... 15

4.2.3 Discussion of testing .......................................................................................................... 16

4.3 Analysis and Testing of F-Canyon Tanks 13.1 and 13.3 Samples............................ 21

4.4 Results............................................................................................................................ 22

4.4.1 Shearing particles lowers particle size ................................................................. 22

4.4.2 Heating changes particles .................................................................................................. 23

4.4.3 Do chemical additives change rheology?.................................................................... 26

4.4.4 Did poor mixing during transfer lead to increase DU concentration in later

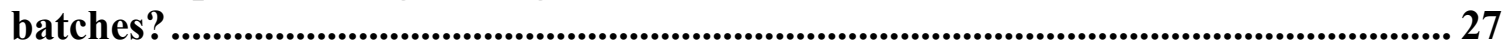

4.4.5 Did precipitation conditions impact flow? .................................................................. 28

4.4.6 Did solids settling increase frictional losses? ...................................................... 30

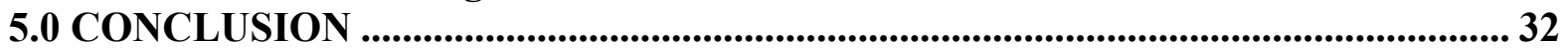

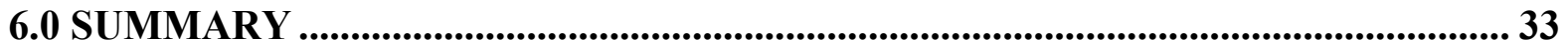

7.0 ACKNOWLEDGEMENTS ............................................................................................ 35

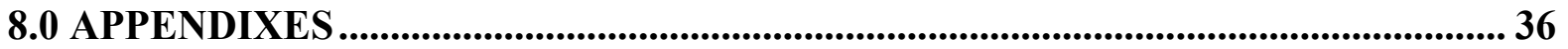

8.1 ADS Analytical Results Summary Table .............................................................. 36

8.2 Simulant RECIPES .......................................................................................................... 36

8.3 Miscellaneous data.......................................................................................................... 36

8.4 Internal Reports............................................................................................................... 36

8.1 ADS Analytical Results Summary Table .............................................................. 37

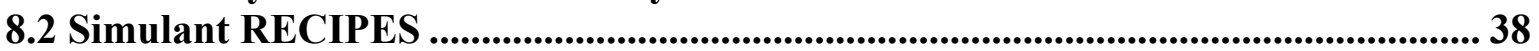

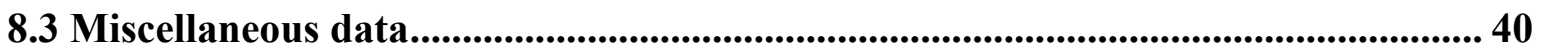

8.4 Internal Reports............................................................................................................ 42

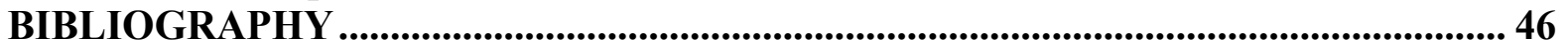




\section{LIST OF FIGURES}

Figure 1 - Schematic of Am/Cm Transfer.......................................................................... 3

Figure 2 - Flow Volume and Flowrate during Transfer Test .......................................... 5

Figure 3 - Simulant Test \# 2 transfer volumes versus time, November 9-10, 2002 ............. 7

Figure 4 - Photograph of Racetrack .............................................................................. 17

Figure 5 - Shearing Test Setup with Waring ${ }^{\circledR}$ Blender.................................................... 18

Figure 6 - Mixing Vessel Setup for Shearing Test........................................................... 19

Figure 7 - Graduated Cylinder Settling Test................................................................. 20

Figure 8 - Particle Size Before and After Shearing in Waring ${ }^{\circledR}$ Blender ............................ 23

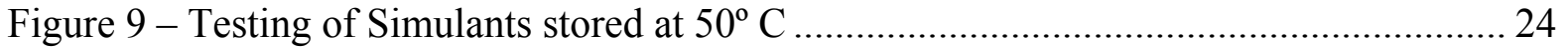

Figure 10 - Concentration Study of Various Simulants ................................................. 26

Figure 11 - Racetrack testing of Simulants with added carbonate, TBP and surfactant ........ 27

Figure 12 Comparison of SEM Photographs of Slow and Fast Caustic Addition................ 28

Figure 13 - Particle Size Distribution Comparison - Fast versus Slow Caustic Addition.... 29

Figure 14 - Concentration study of SRTC Complete Simulant versus F-Canyon Simulant -

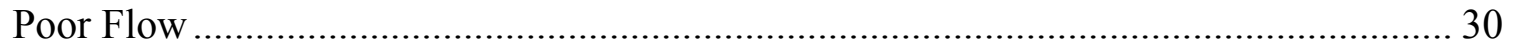

Figure 15 - Settling Graph for Various Slurries......................................................... 31

\section{LIST OF TABLES}

Table 1 - F-Canyon Simulant Preparation for Simulant Test \#1 ......................................... 4

Table 2 - Summary of Plant Conditions and Lab Testing Result........................................ 11

Table 3 -- Recommended Vertical Transport Velocity.................................................. 13

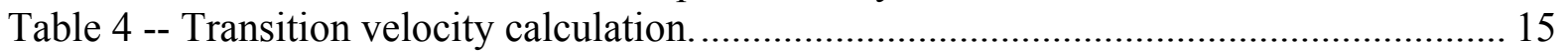

Table 5 - Real Waste and Simulant Preparation ............................................................ 16

Table 6 - Additional Testing Performed ......................................................................... 21

Table 7 - Summary Analysis of F-Canyon Tank 13.1 and 13.3 Samples ............................ 21

Table 8 - Comparison of F-Canyon Simulants................................................................. 22

Table 9 - Dilution Study with F-Canyon Simulant - Poor Flow ....................................... 25 


\section{LIST OF ACRONYMS}

$\begin{array}{ll}\text { ADS } & \text { Analytical Development Section } \\ \text { Am } & \text { Americium } \\ \text { Cm } & \text { Curium } \\ \text { DU } & \text { Depleted Uranium } \\ \text { GC-MS } & \text { Gas Chromatography - Mass Spectrometry } \\ \text { HLW } & \text { High Level Waste } \\ \text { HPLC } & \text { High Performance Liquid Chromatography } \\ \text { IC } & \text { Ion Chromatography } \\ \text { ICP-ES } & \text { Inductively Coupled Plasma - Emission Spectroscopy } \\ \text { ICP-MS } & \text { Inductively Coupled Plasma - Mass Spectroscopy } \\ \text { NaOH } & \text { Sodium Hydroxide } \\ \text { neutralized } & \text { used interchangeably with "caustic added" } \\ \text { SRTC } & \text { Savannah River Technology Center } \\ \text { SVOA } & \text { Semivolatile Organic Analysis } \\ \text { TBP } & \text { tributyl phosphate } \\ \text { U } & \text { Uranium } \\ \text { WPTS } & \text { Waste Processing Technology Section }\end{array}$




\subsection{EXECUTIVE SUMMARY}

30,000 gallons of Americium/Curium $(\mathrm{Am} / \mathrm{Cm})$ slurry was transferred from F-Canyon to Tank $51 \mathrm{H}$ over an 18 hour period between January, 28-29 2003. This was the first continuous transfer of waste from F-Canyon to a waste tank. Prior to the successful $\mathrm{Am} / \mathrm{Cm}$ transfer, the facility had experienced difficulties in transferring simulated solutions, in June 2002 and requested SRTC support in August 2002. A team of personnel from several divisions worked in well-coordinated fashion to determine a cost effective means to identify and mitigate the obstacles to the transfer. The team successfully diagnosed the causes of the problem, replicated the observed behavior in laboratory tests and computer modeling, and recommended controls and changes to facility operations. A successful simulant transfer in December 2002 demonstrated readiness for the $\mathrm{Am} / \mathrm{Cm}$ transfer.

This report summarizes the results of the investigation to determine the cause for the poor flow rate experienced during simulant testing in F-Area. Flow rates as low as 3 gallons per minute (gpm) occurred at the end of the transfer. This report includes an explanation for the low flow rate and recommends controls to prevent the reoccurrence.

Experimental demonstration and analyses identified the high concentration of insoluble solids in the F-Canyon Simulant - Poor Flow as the primary cause for the poor flow rates achieved during the transfers. The insoluble solids concentration measured approximately $33 \%$ higher than targeted $(33 \mathrm{~g} / \mathrm{L})$ and $47 \%$ higher than the nominal DU concentration planned $(30 \mathrm{~g} / \mathrm{L})$ due to inadvertent evaporation. Keeping the concentration near target will minimize flow problems due to concentration. The small solids produced during precipitation also increase particle-particle interactions which contributes to a rheology change in concentrated solutions. The facility should avoid concentration of the solids to maximize the flow rate of the simulant and actual waste.

The elevated temperature during storage of the F-Canyon Simulant in Tank 13.3 also contributed to the poor flow rates. This was not exclusively due to concentrating the simulant but was also due to changes resulting from the high temperature storage. FCanyon personnel installed cooling capability in Tank 13.3 to mitigate and evaporative losses from the slurries. However, the $\mathrm{Am} / \mathrm{Cm}$ waste generates significant heat, approximately 2 watts per gallon, so personnel will need to carefully monitor and control tank temperature, especially while agitating. Personnel need to replace evaporative losses with inhibited water to maintain the concentration in the feed tanks at or below the insoluble solids concentration target.

Some solids settling will occur due to the quick settling solids, the long transfer path and the slow flow rate through the gravity drain lines. As a result, personnel should include the capability for flushing the transfer lines during the transfer as necessary. F-Canyon plans to drain the drain lines prior to performing an inhibited water flush to maximize the effectiveness of line flushing during transfer and will flush the line at the completion of the transfer. Maintaining a maximum velocity during transfer will minimize the solids settling. 
We recommend the following controls to prevent the reoccurrence of slow flows.

1. Control the temperature of the contents of the simulant and real waste storage tanks near ambient during preparation and storage. Temperature control will minimize the inadvertent evaporation of the slurry and minimize any negative impacts of a high temperature during precipitation and storage of the slurry.

2. Avoid any evolution that can inadvertently concentrate the solutions. Well mixed storage tanks and the proper jet or pump operation are necessary to ensure a uniform slurry transfer and avoid concentrating a heel in Tank 13.3.

3. Minimize the air purge rate in the storage tanks after preparation of the simulant and actual waste. The purge leads to slow evaporation of the slurry as well as addition of carbonates, from carbon dioxide sorption.

4. Replace evaporative losses by adding inhibited water as needed.

5. During the transfer of the simulant solids will likely settle in the lines. We recommend intermittent flushing with inhibited water to scour the insoluble solids from the transfer piping. 


\subsection{INTRODUCTION}

Tank 17.1 in F-Canyon contains an americium and curium $(\mathrm{Am} / \mathrm{Cm})$ bearing solution. The Am/Cm components of this solution resulted from the MARK-40 and MARK-41 campaigns during the mid/late 70 's. ${ }^{1}$ Since 1984 , no further additions to Tank 17.1 occurred except to replace evaporative and acid losses. ${ }^{2}$ In 1993, the Department of Energy requested Westinghouse Savannah River Company to evaluate proposed disposition options and provide a recommended disposition option. ${ }^{3}$ More recently, an evaluation identified the most cost-effective method as discarding this material directly to the High Level Waste tanks. ${ }^{4}$

Testing by SRTC in 2001 developed a flowsheet suitable for discarding this material to the HLW tanks. An earlier report summarized the results of experimental demonstrations related to processing of a legacy solution containing americium and curium through the High Level Waste (HLW) system. ${ }^{5}$ The testing included eight experiments covering the baseline, mitigation, and enhanced nitrate processing studies. As a result of these experiments, SRTC recommended using the baseline process as the flowsheet of choice. ${ }^{5}$

Figure 1 provides a schematic of the proposed general disposal path for the legacy solution. The baseline proposal dilutes the solution by adding depleted uranium to help comply with Waste Acceptance Criteria ${ }^{6,7}$ for the tank farm. Addition of $50 \mathrm{wt} \% \mathrm{NaOH}$ solution and dilution water occurs in sufficient volume to produce a resultant slurry with $>1.0 \mathrm{M}$ free hydroxide. Personnel will transfer the slurry first to F-Tank Farm and then to Tank $51 \mathrm{H}$ via an inter-area transfer line. "Inhibited water" (i.e., $0.01 \mathrm{M} \mathrm{NaOH}$ solution) and sludge from Tank $7 \mathrm{~F}$ will follow or accompany the transfers to help scour the high activity solids from the transfer piping.

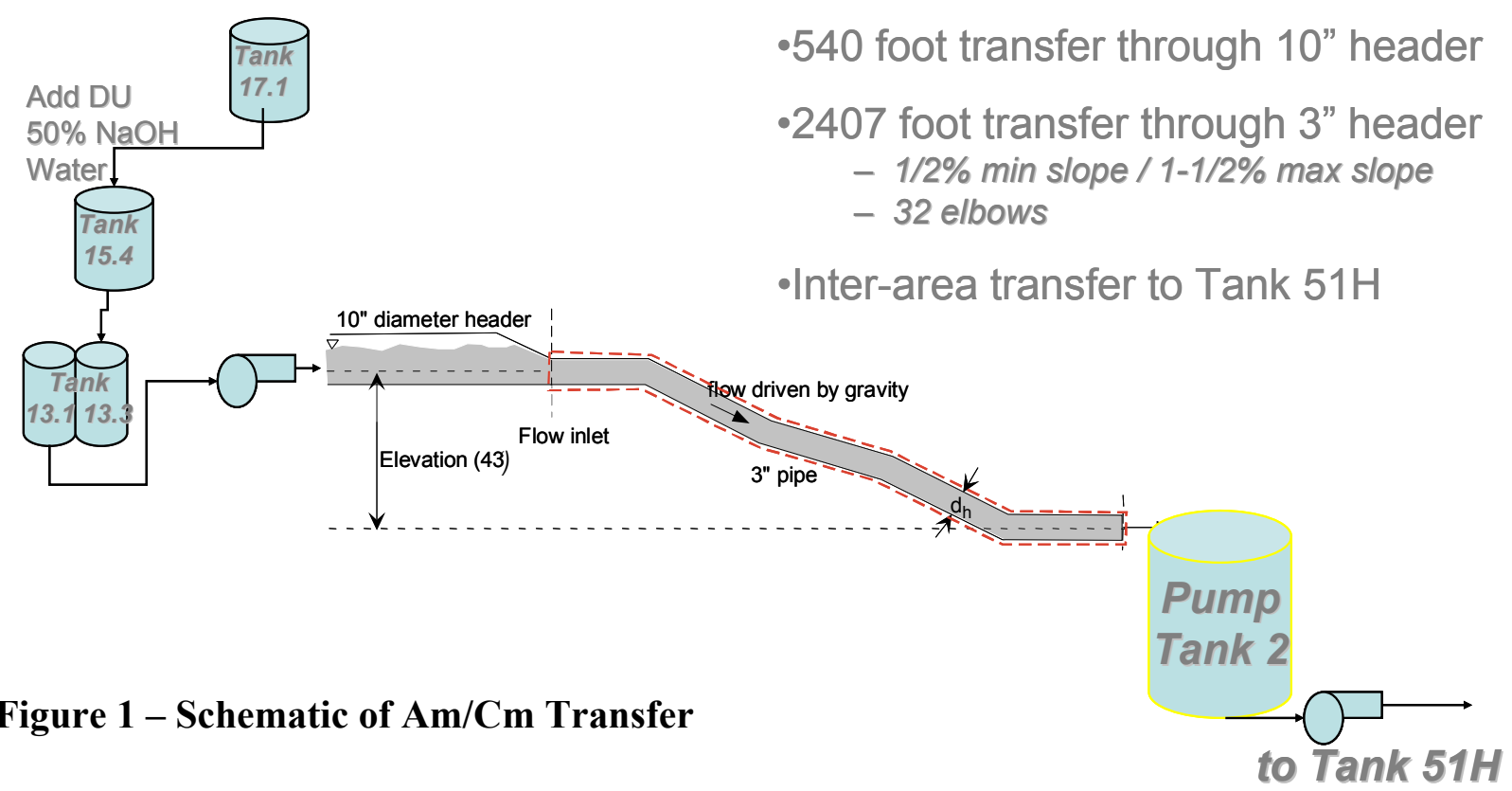




\subsection{DISCUSSION OF SIMULANT TESTING IN F-AREA}

Program management planned testing with simulants to demonstrate the concept of continuous transfer of slurry from Tank 13.1 to Tank $51 \mathrm{H}$. This type of transfer has never been attempted in F-Canyon as typical evolutions involve batch transfers to Pump Tank 2 followed by the transfer of the contents of Pump Tank 2 to the appropriate waste tank. A continuous transfer requires the coordination of both F-Canyon and HLW operations as transfers from Tank 13.3 to Tank 13.1, gravity flow from Tank 13.1 to Pump Tank 2, the addition of 40-50 gpm of flush water to Pump Tank 2, and pumping the diluted slurry through the inter-area transfer line to Tank $51 \mathrm{H}$. Since a continuous transfer, as is planned for the $\mathrm{Am} / \mathrm{Cm}$ real waste, has never been attempted, the program management planned simulant testing to demonstrate this capability.

\subsubsection{Simulant Transfer \#1 (June - September 2002)}

The first demonstration test with simulant was completed between June and September 2002. This test attempted to demonstrate a continuous flowrate of at least 20 gpm through waste header 3 to F Pump Tank 2 with a minimum of 70 gpm flow sustained through the inter-area transfer line to Tank 51. Personnel provided the additional flow in the inter-area transfer line by adding well water in Pump Tank 2. Personnel prepared the simulant used for this testing in F-Canyon Tank 15.4 and transferred it to the bi-cell tanks, 13.1 and 13.3. Tank 13.1 fed the slurry to the gravity drain line between the 10" waste header and Pump Tank 2.

The simulant used in this testing consisted of a simple simulant prepared by combining a DU acid solution, $70 \mathrm{wt} \%$ nitric acid, a 2-3 hour addition of $50 \mathrm{wt} \% \mathrm{NaOH}$, and dilution water. Personnel prepared the simulant in six batches between June 6 and 8, 2002. Table 1 summarizes the recipes used in the simulant development. The targeted concentration for these batches was $33 \mathrm{~g} / \mathrm{L}$ (insoluble solids concentration of $3.5 \mathrm{wt} \%$ ).

Table 1 - F-Canyon Simulant Preparation for Simulant Test \#1

\begin{tabular}{|l|c|c|c|c|c|c|c|}
\hline & Batch \#1 & Batch \#2 & Batch \#3 & Batch \#4 & Batch \#5 & Batch \#6 & Total \\
\hline $273 \mathrm{~g} / \mathrm{L} \mathrm{DU}$ & $3,532 \mathrm{lb}$ & $3,531 \mathrm{lb}$ & $3,888 \mathrm{lb}$ & $3,621 \mathrm{lb}$ & $3,692 \mathrm{lb}$ & $3,692 \mathrm{lb}$ & $21,956 \mathrm{lb}$ \\
\hline $\begin{array}{l}70 \mathrm{wt} \% \text { nitric } \\
\text { acid }\end{array}$ & $1,813 \mathrm{lb}$ & $1,813 \mathrm{lb}$ & $1,812 \mathrm{lb}$ & $1,813 \mathrm{lb}$ & $1,813 \mathrm{lb}$ & $1,813 \mathrm{lb}$ & $10,877 \mathrm{lb}$ \\
\hline $50 \mathrm{wt} \% \mathrm{NaOH}$ & $4,673 \mathrm{lb}$ & $4,859 \mathrm{lb}$ & $4,627 \mathrm{lb}$ & $4,625 \mathrm{lb}$ & $4,644 \mathrm{lb}$ & $4,644 \mathrm{lb}$ & $28,072 \mathrm{lb}$ \\
\hline Process water & $14,245 \mathrm{lb}$ & $14,063 \mathrm{lb}$ & $14,187 \mathrm{lb}$ & $14,204 \mathrm{lb}$ & $14,144 \mathrm{lb}$ & $14,144 \mathrm{lb}$ & $84,987 \mathrm{lb}$ \\
\hline Total & $24,263 \mathrm{lb}$ & $24,266 \mathrm{lb}$ & $24,514 \mathrm{lb}$ & $24,263 \mathrm{lb}$ & $24,293 \mathrm{lb}$ & $24,293 \mathrm{lb}$ & $145,892 \mathrm{lb}$ \\
\hline spg & 1.13 & 1.14 & 1.14 & 1.13 & 1.13 & 1.13 & 1.133 \\
\hline volume, gal & 2,573 & 2,551 & 2,577 & 2,573 & 2,576 & 2,576 & 15,426 \\
\hline
\end{tabular}

The initial transfer between Tank 13.1 and Pump Tank 2 started on August 16 with a one hour jet transfer of 1425 gallons (Average rate $=24 \mathrm{gpm}$ )

A second transfer between Tank 13.1 and Pump Tank 2 began on August 16 with a 6.6 hour transfer using the 1AF Transfer pump. Personnel transferred a total of 5,530 gallons of 
simulant at an average flowrate of $13.9 \mathrm{gpm}$. However, decrease in flow occurred at approximately 0200 on August 17 as shown in Figure 2 below. This event occurred at approximately the same time that the Tank 13.3 simulant transfer into Tank 13.1 started (i.e., approximately 0205 to 0305 ).

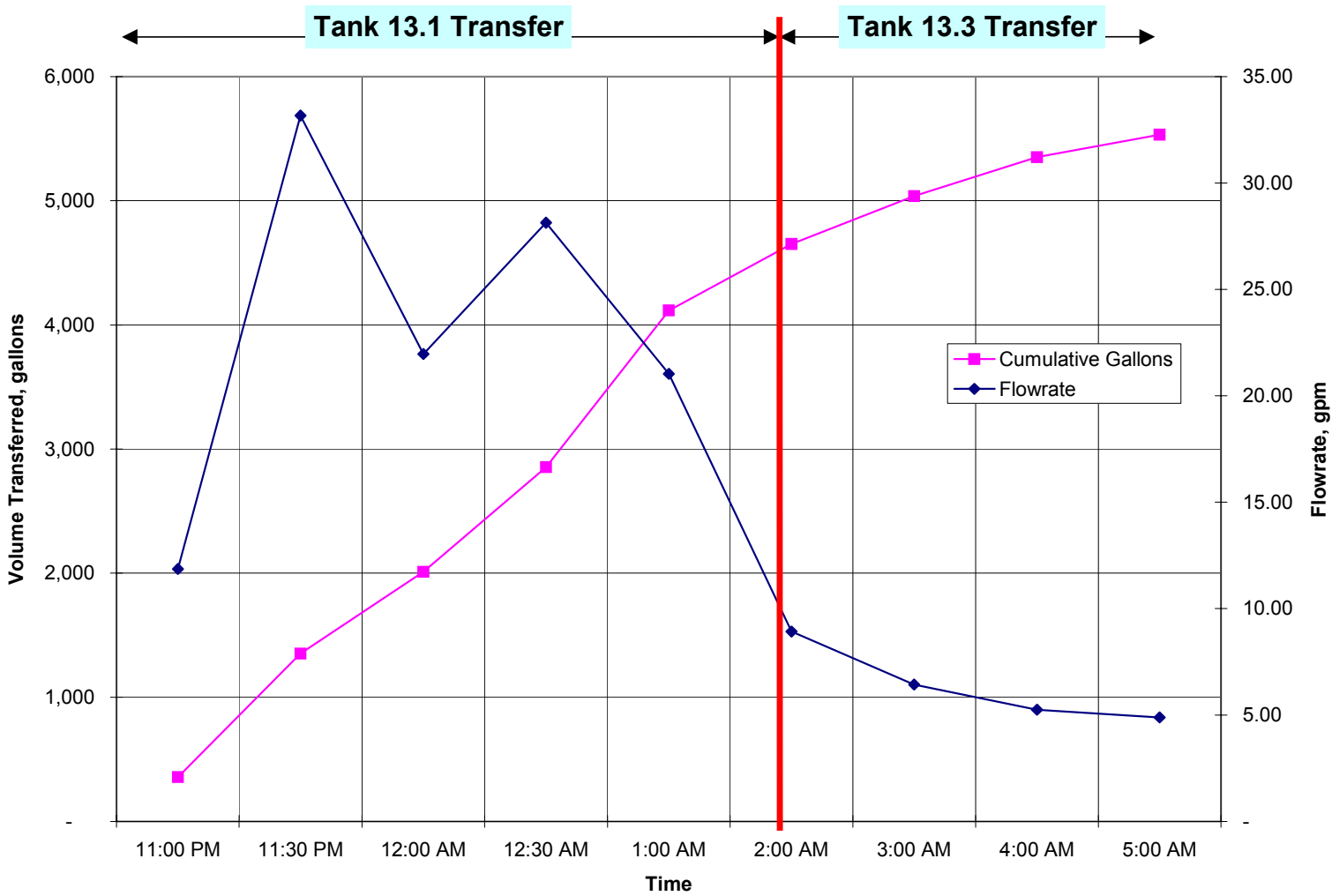

Figure 2 - Flow Volume and Flowrate during Transfer Test

A third transfer between Tank 13.1 and Pump Tank 2 began on August 17 with a three hour transfer using the 1AF Transfer pump. Personnel transferred a total of 4,120 gallons of simulant at an average flowrate of $22.9 \mathrm{gpm}$.

A fourth transfer between Tank 13.1 and Pump Tank 2 started on September 24 with a four hour transfer using first the $1 \mathrm{AF}$ Transfer pump and then the Jet. Personnel transferred a total of 1,010 gallons of simulant at an average flowrate of $4.1 \mathrm{gpm}$.

A 2500 gallon hot water flush of waste header \#3 occurred on October 2 and 3 with an average flow rate of $15.5 \mathrm{gpm}$.

A fifth transfer between Tank 13.1 and Pump Tank 2 started on October 5 with a 50 minute transfer using first the Jet. The average flowrate for the total of 585 gallons of simulant equaled $11.7 \mathrm{gpm}$. 


\subsubsection{Tank Cleaning and Pipe Flushing}

Program management decided (Appendix 8.4.1) to discard the F Canyon Simulant - Poor Flow used in the first simulant test, to clean the precipitate tanks using an acid wash, to flush the transfer lines with inhibited water, and to prepare new simulant for a second transfer test. Based on results from SRTC experiments - see section 4.4.2.1 - personnel added inhibited water to the F-Canyon simulant, diluting by $54 \mathrm{vol} \%$, and transferred to the F Tank Farm.

In addition to the dilution for this transfer, we recommended a number of additional controls to maximize the flowrate of the simulant during the transfer test (Appendix 8.4.2).

$>$ Cool tank

$>$ Minimize agitation

$>$ Minimize storage time

$>$ Flush as needed

\subsubsection{Simulant Transfer \#2 (November - December, 2002)}

Program management defined two tests demonstrate the continuous transfer of simulant from Tanks 13.1 and 13.3 to Tank 51H: an initial 2000 gal transfer just through the gravity drain line and a longer duration transfer involving the entire flow path to Tank $51 \mathrm{H}$

\subsubsection{2000 Gallon Simulant Transfer (November 9-10, 2002)}

The first test involved a 2,000 gallon transfer from Tank 13.1 to Pump Tank 2. This evolution occurred on November 9 and 10, 2002. Personnel transferred approximately 1890 gallons of precipitate into the waste header from Tank 13.1 during 65 minutes of pumping. The average flowrate during this transfer equaled $28.7 \mathrm{gpm}$. Personnel recorded an average flowrate of material received in Pump Tank 2 of 28.6 gpm during the first 60 minutes of receipt in Pump Tank 2. Figure 3 summarizes the data collected during this transfer. 
WSRC-TR-2002-00569, REV. 0

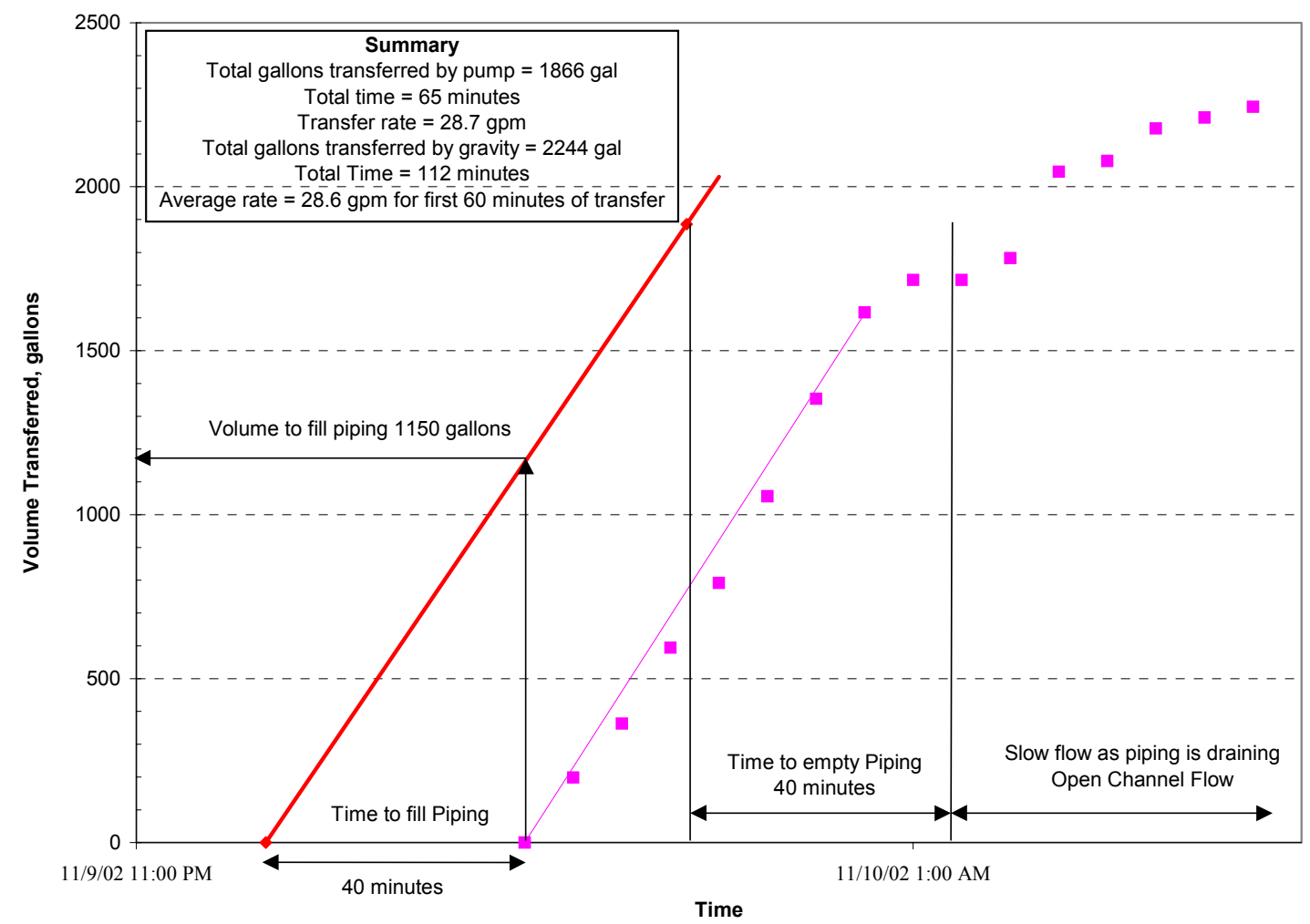

Figure 3 - Simulant Test \# 2 transfer volumes versus time, November 9-10, 2002

This short transfer included approximately $7 \%$ of the volume planned during the actual waste transfer with much of the transfer time spent filling the piping. This data shows it takes approximately 40 minutes after beginning the transfer from Tank 13.1 before the volume begins increasing in Pump Tank 2. Hence, the evolution required approximately 1150 gallons to fill the 10" header and 3" gravity drain line. With an average 29 gpm flow, it took approximately 40 minutes after pumping from Tank 13.1 stops before the flow to Pump Tank 2 decreased. After the drain lines emptied, slug flow occurred instead of the average $29 \mathrm{gpm}$ flow observed during most of the transfer. Pump Tank 2 also received a greater volume (i.e., $378 \mathrm{gal}$ ) than personnel pumped from Tank 13.1. This volume corresponds to the priming water used in starting the pump and is insignificant compared to the total volume that will be transferred to Tank $51 \mathrm{H}$ (i.e., $\sim 150,000$ gallon).

The simulant in Tank 13.1 proved more dilute than planned. Analyses indicated a Depleted Uranium (DU) concentration of $24 \mathrm{~g} / \mathrm{L}, 27 \%$ below the $33 \mathrm{~g} / \mathrm{L}$ target. As such, this transfer does not bound the planned evolution with actual waste. The low concentration occurred due to a nitric acid heel present before adding the simulated waste. Personnel corrected for the acid by the addition of sodium hydroxide. In addition, the Tank 13.3 steam jet adds significantly more steam than planned to jet the simulant solution to Tank 13.1. 


\subsubsection{8000 Gallon Simulant Transfer (December 10, 2002)}

The second transfer moved 8,000 gallon from Tank 13.1 to Pump Tank 2 concurrent with a continuous transfer from Pump Tank 2 to Tank 51. This operation successfully completed on December 10, 2002. Personnel transferred approximately 14,600 gallons of precipitate and flush water into the waste header from Tank 13.1 over 9 hours. The average flowrate during this transfer equaled $27 \mathrm{gpm}$. Personnel recorded an average flowrate of material pumped from Pump Tank 2 to Tank 51 of $\sim 30$ gpm during the $\sim 4$ hours of receipt in Pump Tank 2. Figure 3 summarizes the data collected during this transfer.

During this transfer, personnel flushed the gravity drain line with $\sim 18000$ gallons of inhibited water. In addition, personnel completed a 2000 gallon flush after the simulant transfer. 


\subsection{TEST REQUIREMENTS}

F-Canyon Engineering requested that SRTC complete testing and perform engineering calculations to answer the following questions.

1. What short term fix is needed to disposition the slow flowing simulant?

2. What controls are needed to ensure the success of future transfers?

3. Why did the F Canyon Simulant - Poor Flow, flow slowly?

- Include testing to duplicate the poor flow.

4. What will happen in future simulant and actual waste transfers? 


\subsection{EXPERIMENTAL AND ENGINEERING STUDIES}

We performed a series of tests and engineering calculations to understand the cause of the slow flow and to determine controls to prevent a reoccurrence. Researchers in the Waste Processing Technology section of SRTC performed or coordinated the work discussed below. The researchers received excellent support from the engineers and operations personnel in F-Canyon and HLW in understanding the preparation of the simulant, the conditions during the storage preceding the prior slow transfers, the facility design limitations, and the details of the planned transfer with actual waste.

\subsection{DISCUSSION OF POSSIBLE CAUSES FOR POOR FLOW}

Team members identified a number of potential causes for the F Canyon Simulant - Poor Flow slurry and we structured our test program around these variables. The transfer of the contents Tank 13.3 slurry flowed notably slower than the initial transfer from Tank 13.1 on August 16. Personnel collected samples of the slurry (pulled from Tank 13.1) and shipped to SRTC for testing. The initial investigation focused on the following two questions.

What was different about the solution stored in Tank 13.3?

What was different about the storage of this material?

The team postulated the following potential causes and we studied these lines of inquiry during this investigation.

1. High slurry temperature: Tank 13.3 operated without cooling whereas Tank 13.1 operated with cooling. Due to the heat input from agitation, the slurry temperature reached approximately $50^{\circ} \mathrm{C}$ during storage.

2. High slurry concentration: Storage at $50^{\circ} \mathrm{C}$ led to evaporation of water from the slurry, causing the DU concentration to increase to $44 \mathrm{~g} / \mathrm{L}$, above its target of $33 \mathrm{~g} / \mathrm{L}$.

3. Particle shearing causing small particles: The slurry in both tanks received continuous agitation throughout storage. Since flow behavior appeared to decline with time, the potential existed that prolonged agitation of the Tank 13.3 material resulted in particle attrition and altered the rheology.

4. Additives post precipitation: Personnel added a mixture of rainwater and lab waste to the Tank 13.3 slurry to replace evaporative losses. This lab waste solution consisted of a caustic solution with primarily DU as the insoluble solid. The lab waste contained a variety of chemical constituents, including surfactants may have modified the particleparticle interaction of the slurry.

5. Carbon dioxide sorption: Strong caustic solutions readily absorb carbon dioxide. The tank's air purge provides a source of carbon dioxide. The material in Tank 13.3 experienced prolonged storage and the carbonates may have altered the behavior.

6. Solids Settling and Plugging the Transfer Line: The accumulation of solids, caused by rapid settling rates, low flowrates, and long transfer durations, may have caused flow degradation during testing.

7. Precipitation Rate: The precipitation rate, controlled by the precipitation kinetics and the caustic addition rate will effect the particle size and the particle size distribution. 


\subsection{TESTING AND STUDIES TO DETERMINE CAUSE}

We completed a series of tests and two hydraulic calculations in an attempt to understand the poor flowrates achieved in F-Canyon testing. The following sections describe the hydraulic studies and testing. Table 2 summarizes the tests performed and the impact on each on a "standardized race track" flow test (described in a later section).

Table 2 - Summary of Plant Conditions and Lab Testing Result

\begin{tabular}{|c|c|c|}
\hline Plant Conditions & Lab Test & Racetrack Result \\
\hline Agitated 3 months & Blender Test & No Impact \\
\hline $\begin{array}{l}\text { Heated Solution to } \\
50^{\circ} \mathrm{C}, 3 \text { months }\end{array}$ & $\begin{array}{l}\text { Water Bath, } 50^{\circ} \mathrm{C}, 1 \\
\text { month }\end{array}$ & $\begin{array}{l}\text { Reduced Flow } 2 \mathrm{X} \text { for one } \\
\text { simulant }\end{array}$ \\
\hline $\begin{array}{l}\text { Added lab waste to } \\
\text { replace evaporative } \\
\text { losses }\end{array}$ & $\begin{array}{l}\text { Added TBP and other } \\
\text { surfactants }\end{array}$ & No Impact \\
\hline $\begin{array}{l}\mathrm{CO}_{2} \text { sorption over } 3 \\
\text { months }\end{array}$ & $\begin{array}{l}\text { Added sodium } \\
\text { carbonate }\end{array}$ & No Impact \\
\hline $\begin{array}{l}\text { Precipitated over } 3 \\
\text { hours }\end{array}$ & $\begin{array}{l}\text { Slow vs. fast caustic } \\
\text { addition }\end{array}$ & \multirow[t]{2}{*}{$\begin{array}{l}\text { Slow caustic addition and } \\
\text { higher solids reduced flow } \\
10 \mathrm{X}\end{array}$} \\
\hline $\begin{array}{l}\text { Depleted Uranium } \\
33 \% \text { more } \\
\text { concentrated than } \\
\text { target }\end{array}$ & Vary wt \% solids & \\
\hline
\end{tabular}

\subsubsection{Hydraulic Calculations}

Personnel completed two sets of hydraulic calculations to aid in the understanding of the low flow rates in the F-Canyon test. The first calculation used a model ${ }^{8}$, completed by Si Young Lee, predicting the expected gravity flow through the 10" and 3 " drain lines. Using the transfer data from the facility, Lee concluded that the existing pipe is rougher than a newly installed pipe, and exhibits approximately the roughness of a cement pipe. These properties lead to an expected maximum flow through the piper for water of $65 \mathrm{gpm}$. The predicted flow for the slow flowing simulant equals $43 \mathrm{gpm}$, assuming the yield stress and consistency measured by SRTC and using a power law prediction for rheology. Thus the expected maximum flow falls measurably below the prior prediction ${ }^{9}$ but still well above the values observed in August through September.

The second calculation, completed by Michael Poirier (included below in this report), predicted the flow velocity in the 10 " and 3" pipe necessary to keep solids suspended during 
transfer. The minimum velocity to prevent solids settling significantly exceeds the planned 20-30 gpm flow. As a result, some particles will settle during the transfer and we recommend intermittent flushing to maximize slurry flow.

SRTC performed the analysis by reviewing available information on the properties of the solids and fluid that need to be transported and by reviewing the technical literature for information on transporting slurries through pipelines.

Modeling by S. Y. Lee and M. Poirier required the following assumptions:

- The particle density is $3.93 \mathrm{~g} / \mathrm{cc}$.

- The fluid density is $1.138 \mathrm{~g} / \mathrm{cc}$.

- The fluid viscosity is $1.8 \mathrm{cp}$.

- The particle concentration is $10 \%$.

- The pipe diameter is 3 inch.

- $\quad$ The particle size is $11 \mu, 88 \mu$, and $248 \mu$.

\section{Vertical Pipelines}

One guideline for transporting solid particles in vertical pipelines is for the bulk fluid velocity to be greater than twice the particle settling velocity. ${ }^{10,11,12}$

The particle settling velocity is calculated by the following equations. ${ }^{13}$

$$
\begin{array}{ll}
\mathrm{v}_{\mathrm{s}}=\mathrm{g}(\mathrm{s}-1) \mathrm{d}_{\mathrm{p}}{ }^{2} / 18 v & \text { for } \operatorname{Re}_{\mathrm{p}}<1.4 \\
\mathrm{v}_{\mathrm{s}}=0.13[\mathrm{~g}(\mathrm{~s}-1)]^{0.72} \mathrm{~d}_{\mathrm{p}}^{1.18} \mathrm{v}^{-0.45} & \text { for } 1.4<\mathrm{Re}_{\mathrm{p}}<500 \\
\mathrm{v}_{\mathrm{s}}=1.74\left[\mathrm{~g}(\mathrm{~s}-1) \mathrm{d}_{\mathrm{p}}\right]^{0.5} & \text { for } \operatorname{Re}_{\mathrm{p}}>500 \\
\operatorname{Re}_{\mathrm{p}}=\mathrm{d}_{\mathrm{p}} \mathrm{v}_{\mathrm{s}} / v &
\end{array}
$$

where $\mathrm{v}_{\mathrm{s}}$ is the settling velocity, $\mathrm{g}$ is the acceleration due to gravity, $\mathrm{s}$ is the ratio of particle and fluid densities ( $\mathrm{s}=$ particle density/fluid density), $\mathrm{d}_{\mathrm{p}}$ is the particle diameter, and $v$ is the fluid kinematic viscosity $(v=\mu / \rho)$.

To perform the calculation, one assumes a particle Reynolds number, calculates the settling velocity with the appropriate equation, and calculates a new particle the Reynolds number with the calculated settling velocity. If the Reynolds number is in the correct range for the equation used, the calculated settling velocity is correct. If the Reynolds number is not in the correct range for the equation used, use a different equation to calculate the settling velocity. Repeat these steps as necessary.

Table 3 shows the calculated settling velocity as well as the recommended transport velocity in vertical pipelines. 
WSRC-TR-2002-00569, REV. 0

\section{Table 3 -- Recommended Vertical Transport Velocity}

$\begin{array}{ccc}\text { Particle Size }(\mu) & \text { Calculated Settling Velocity }(\mathrm{ft} / \mathrm{s}) & \text { Required Transport Velocity }(\mathrm{ft} / \mathrm{s}) \\ 11 & 0.00034 & 0.00068 \\ 88 & 0.022 & 0.044 \\ 248 & 0.096 & 0.192\end{array}$

\section{Horizontal Pipelines}

Solid-liquid horizontal flow can occur in a number of different flow regimes. ${ }^{14,15,16,17}$ The primary parameters influencing flow regimes are velocity and particle size. The common flow regimes are pseudo-homogeneous suspensions, heterogeneous suspensions, heterogeneous suspensions with sliding beds, and stationary beds. Pseudo-homogeneous suspensions occur at high velocities with small particles. The particles move at the same velocity as the fluid with a uniform distribution across the pipe. With slower velocities and larger particles, heterogeneous suspensions occur. The concentration of particles across the pipe is not uniform, and the particle velocity is slightly less than the fluid velocity. At low velocities with large particles, a heterogeneous suspension with a sliding bed occurs. Particles in upper part of the pipe are in suspension and move with the liquid, while particles in the bottom of the pipe form a bed of solids which moves at a slower, uniform rate. At very low velocities with large particles, a stationary bed occurs. The upper part of the pipe contains a suspension, while the lower part contains a deposit, the surface layers of which move.

The conditions at which sliding and stationary beds occur are of interest because these conditions are normally undesirable. A sliding bed can cause substantial pipe abrasion. Sliding and stationary beds lead to low transport efficiencies. The transition between a heterogeneous suspension and a heterogeneous suspension with a sliding bed is often called the deposition velocity or re-suspension velocity, depending on whether the velocity is decreasing or increasing. ${ }^{9}$ The axial velocity in a transfer line should be greater than the deposition velocity or re-suspension velocity. Slurry transfers should occur as heterogeneous suspensions. ${ }^{12,18}$

One correlation frequently employed to calculate minimum transport velocities (i.e. for heterogeneous suspensions) in horizontal pipelines is the Durand equation. ${ }^{11,12,19}$ The correlation was developed for coarse particles, and it does not account for differences in particle size. Equation [5] describes the correlation

$$
v_{t}=F[2 g(s-1) D]^{1 / 2}
$$

where $\mathrm{v}_{\mathrm{t}}$ is the minimum transport velocity, $\mathrm{F}$ is an empirical constant that varies between 0.4 and $1.5, \mathrm{~s}$ is the ratio of particle density to fluid density, and $\mathrm{D}$ is the pipe diameter. Using a value of 1.5 for F, 3.45 for $\mathrm{s}$, and 3 inches for the pipe diameter, the calculated minimum 
transport velocity is $5.5 \mathrm{ft} / \mathrm{sec}$. This correlation does not enable one to calculate the transition between a heterogeneous suspension with a sliding bed and a stationary bed.

Wasp ${ }^{11}$ added a correction to the Durand equation to account for the influence of particle size $\left(d_{p}\right)$. Using this correction, the modified Durand equation is described by equation [6].

$$
\mathrm{v}_{\mathrm{t}}=\mathrm{F}[2 \mathrm{~g}(\mathrm{~s}-1) \mathrm{D}]^{1 / 2}\left(\mathrm{~d}_{\mathrm{p}} / \mathrm{D}\right)^{1 / 6}
$$

This correlation does not enable one to calculate the transition between a heterogeneous suspension with a sliding bed and a stationary bed. Using this correlation, the required transport velocity is $2.2-3.6 \mathrm{ft} / \mathrm{s}$.

Turian et. al reviewed a collection of 864 experimental critical velocity data and developed the following correlation

$$
\mathrm{v}_{\mathrm{t}}=[2 g D(s-1)]^{0.5}(1.7951) C^{0.1087}(1-C)^{0.2501}\left\{\frac{D \rho[g D(s-1)]^{0.5}}{\mu}\right\}^{0.00179}\left(\frac{d_{p}}{D}\right)^{0.06623}
$$

where $\mathrm{C}$ is particle concentration. ${ }^{20}$ Using there correlation, one calculates a transition velocity of $4.8-5.9 \mathrm{ft} / \mathrm{s}$.

Another correlation that can be applied is the one developed by Walton and described by

$$
\mathrm{v}_{\mathrm{t}}=v_{s} \frac{71.2}{\operatorname{Re}_{c}^{*}}\left(\frac{D}{d_{p}}\right)\left(\frac{\mu}{\rho D}\right)^{1 / 3}
$$

where $\operatorname{Re}_{\mathrm{c}}{ }^{*}$ is the critical Reynolds number, which is a function of particle concentration. ${ }^{21}$ For a particle concentration of $10 \%$, its value is 4.46. Applying the Walton correlation, one calculates the transition velocity to be $1.1-2.0 \mathrm{ft} / \mathrm{s}$.

Table 4 summarizes the results. The most conservative approach for determining the minimum transport velocity for a heterogeneous suspension would be to select the maximum value from Table $2(9.4 \mathrm{ft} / \mathrm{sec})$. Another approach is to take the average of the four values $(4.4-5.2 \mathrm{ft} / \mathrm{s})$. 
Table 4 -- Transition velocity calculation.

\begin{tabular}{|c|c|c|c|}
\hline Correlation & $\mathrm{v}_{\mathrm{t}}(11 \mu)$ & $\mathrm{v}_{\mathrm{t}}(88 \mu)$ & $\mathrm{v}_{\mathrm{t}}(248 \mu)$ \\
\hline Durand & 9.4 & 9.4 & 9.4 \\
\hline Wasp & 2.2 & 3.0 & 3.6 \\
\hline Turian et. al. & 4.8 & 5.5 & 5.9 \\
\hline Walton & 1.1 & 1.8 & 2.0 \\
\hline Average & 3.6 & 4.0 & 4.2 \\
\hline
\end{tabular}

Since the Durand correlation does not account for particle size and was developed for large particles, the best approaches would be to take the average of the four correlations $(4.4-5.2$ $\mathrm{ft} / \mathrm{s})$, average the Turian, Wasp, and Walton correlations $(2.7-3.8 \mathrm{ft} / \mathrm{s})$, or use the Turian correlation since it is most conservative $(4.8-5.9 \mathrm{ft} / \mathrm{s})$.

Since the slurry is composed of a mixture of particle sizes, the fine particles that are easily suspended will reduce the settling rate of the coarse particles and thereby reduce the minimum transport velocity.

Based on the above analysis, flushing of the transfer line after transfer is needed as solids are expected to settle in the transfer line.

\subsubsection{Preparation of simulants and real waste}

Peters et al demonstrated the planned disposal in 2001 with actual waste. ${ }^{5}$ We used the residual material in this investigation as appropriate. We also prepared a number of simulants for this study. Table 5 summarizes the composition of the prepared simulants. Appendix 8.2 summarizes the preparation of these slurries. 
WSRC-TR-2002-00569, REV. 0

Table 5 - Real Waste and Simulant Preparation

\begin{tabular}{|c|c|c|c|}
\hline Simulant & DU Source & $\begin{array}{c}\text { Am-Cm } \\
\text { Slurry }\end{array}$ & $\begin{array}{c}\text { Final DU, } \\
\text { g/L }\end{array}$ \\
\hline SRTC Am/Cm Actual Waste 2001 & $\begin{array}{c}\text { F-Canyon } \\
\text { Supplied DU } \\
350 \mathrm{~g} / \mathrm{L}\end{array}$ & $\begin{array}{c}\text { Tank } 17.1 \\
\text { solution } \\
\text { Actual Waste }\end{array}$ & $24.0 \mathrm{~g} / \mathrm{L}$ \\
\hline SRTC Complete Simulant & $\begin{array}{c}\text { F-Canyon } \\
\text { Supplied DU } \\
273 \mathrm{~g} / \mathrm{L}\end{array}$ & $\begin{array}{c}\text { Tank } 17.1 \\
\text { Simulant }\end{array}$ & $24.2 \mathrm{~g} / \mathrm{L}$ \\
\hline SRTC Complete Simulant - Fe for DU & N/A & $\begin{array}{c}\text { Tank } 17.1 \\
\text { Simulant }\end{array}$ & N/A \\
\hline SRTC Simulant - Fast Caustic Addition & $\begin{array}{c}\text { SRTC } \\
\text { Produced DU } \\
400 \mathrm{~g} / \mathrm{L} \text { DU }\end{array}$ & $\begin{array}{c}70 \mathrm{wt} \% \\
\text { nitric acid }\end{array}$ & $33 \mathrm{~g} / \mathrm{L}$ \\
\hline SRTC Simulant - Slow Caustic Addition & $\begin{array}{c}\text { F-Canyon } \\
\text { Supplied DU } \\
273 \mathrm{~g} / \mathrm{L}\end{array}$ & $\begin{array}{c}70 \mathrm{wt} \% \\
\text { nitric acid }\end{array}$ & $33 \mathrm{~g} / \mathrm{L}$ \\
\hline
\end{tabular}

\subsubsection{Discussion of testing}

We structured the experimental design to investigate the variables discussed previously (i.e., temperature, chemical additives - e.g., carbonates, surfactants, lab waste, rate of precipitation, agitation). Most of the effort consisted of single-effect tests of simplified design. Later tests increased in complexity and focused on interactions of the variables.

\subsubsection{Flow rate testing in "race track"}

We developed a "standard race track" flow test patterned after that used in the prior study by Peters. This test provided a relative measure of the flow behavior for different slurries or for slurries after heating and agitation. The SRTC glass shop fabricated the race track. Figure 4 shows a race track. The race track consists of a $50 \mathrm{~mL}$ reservoir at the top of the tubing and a 14 " condenser coil (5.9 mm ID, approximately $31 \mathrm{~cm}$ length).

Testing involved adding $30 \mathrm{~mL}$ of simulant into the reservoir and measuring the elapsed time until all the simulant exited the race track. We tested with water (results in notebook ${ }^{22}$ ) to ensure consistent behavior from one day to the next. 


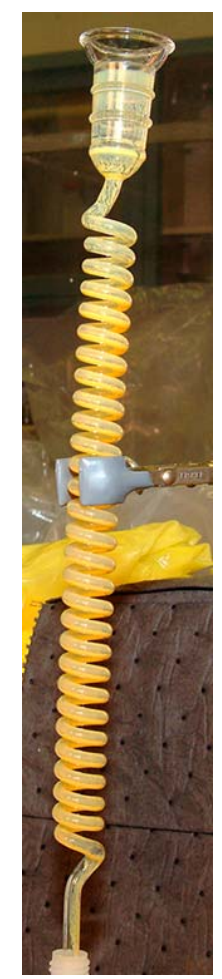

\section{Figure 4 - Photograph of Racetrack}

\subsubsection{Particle shearing tests}

We used two types of particle shearing tests as described below.

\subsection{Blender tests}

Initial testing involved adding approximately $200 \mathrm{~mL}$ of simulant to a two-speed commercial Waring ${ }^{\circledR}$ blender. A photograph, Figure 5, shows the setup of the blender in a hood.

We selected the blender because of the high shear rate and availability. However, we observed two problems during testing. First, the solutions heated rapidly during testing. When adding the minimum practical volume of solution, the contents heated rapidly to as high as $80^{\circ} \mathrm{C}$. The high temperature also led to quick evaporation in the blender. As a result, personnel added water to the samples to replace evaporative losses and used ice vests to cool the slurries. The blenders exhibited a short life in this testing. The high temperatures led to warping of the plastic lid and failure of the motor. The useful life of the blenders proved less than 8 hours. We used three different blenders during the testing. Because of these problems, we installed an agitator to complete additional experiments. 


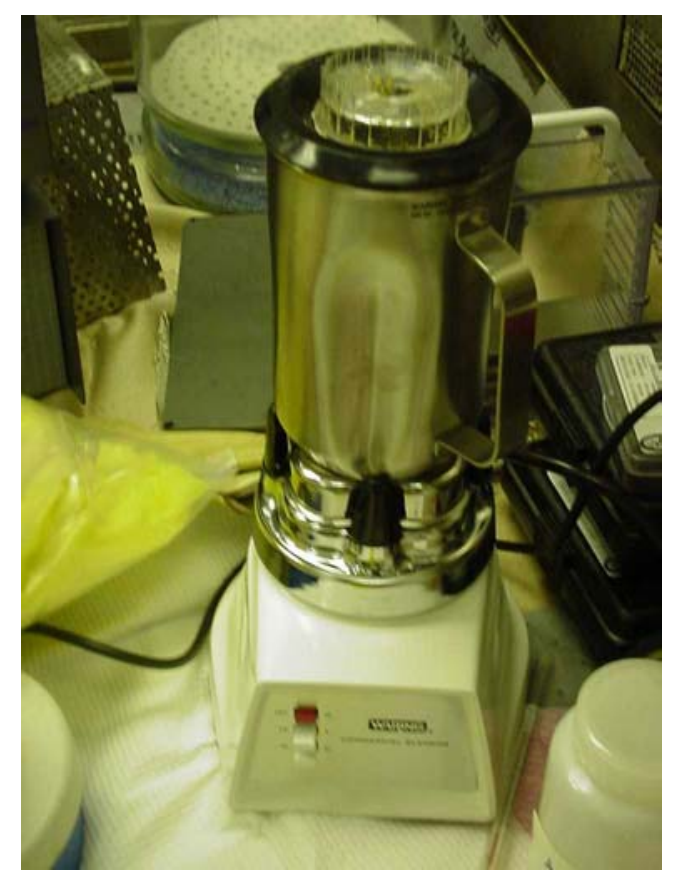

Figure 5 - Shearing Test Setup with Waring® Blender

\subsection{Agitator tests}

Figure 6 shows the experimental configuration using an agitator. The mixing vessel consisted of a 1.1 liter stainless beaker with 4 welded baffles. The agitator was driven by a Labline Laboratory Stirrer with a $41.4 \mathrm{~W}$ motor at a speed of $600 \mathrm{rpm}$. The design included a single $4.45 \mathrm{~cm}$ diameter flat blade agitator. Tests used approximately $280 \mathrm{~mL}$ of simulant (equating to $4.45 \mathrm{~cm}$ of liquid height). Personnel placed Parafilm ${ }^{\mathrm{TM}}$ on the top of the beaker to minimize evaporation and added water as needed to replace evaporative losses. 

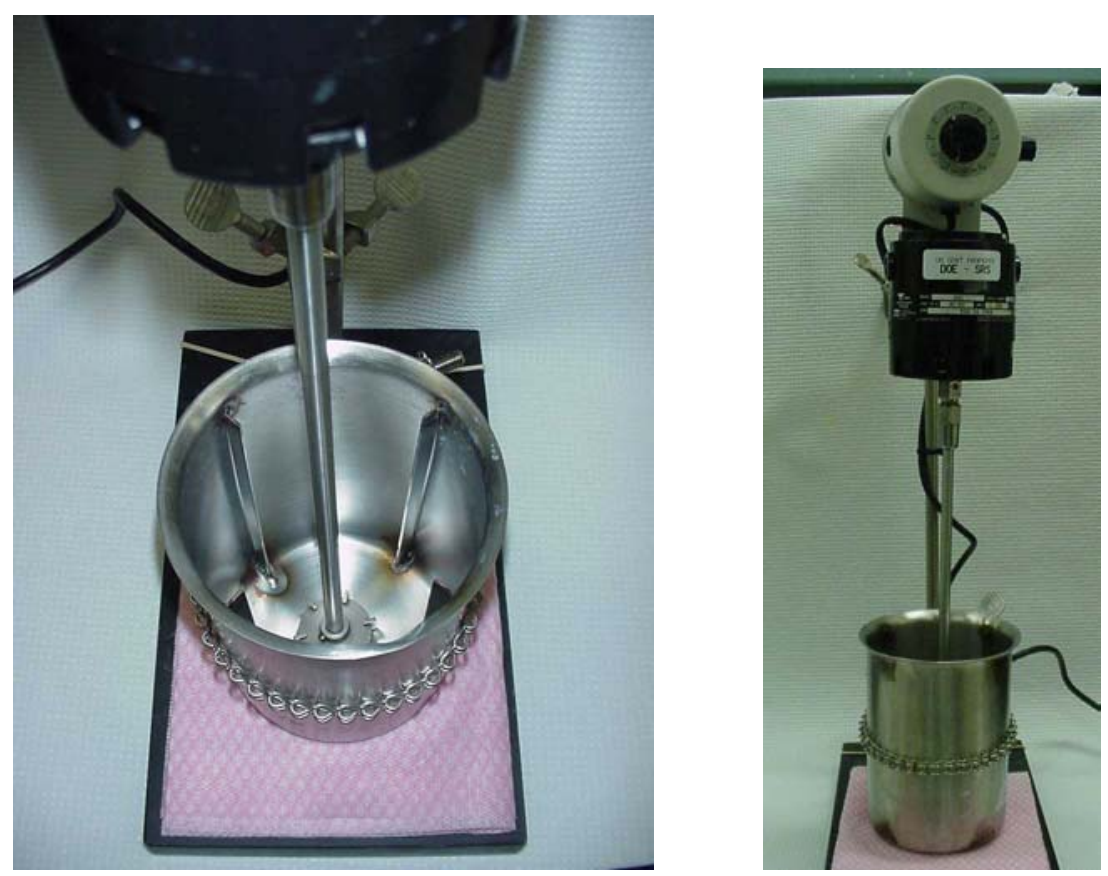

Figure 6 - Mixing Vessel Setup for Shearing Test

\subsubsection{Settling testing}

Settling testing occurred in graduated cylinders to determine the settling rate and settling density for the insoluble solids. We videotaped most of the settling studies as the settling studies proceeded fairly slow with many experiments extended to 24 hours. Figure 7 shows a typical setup. 


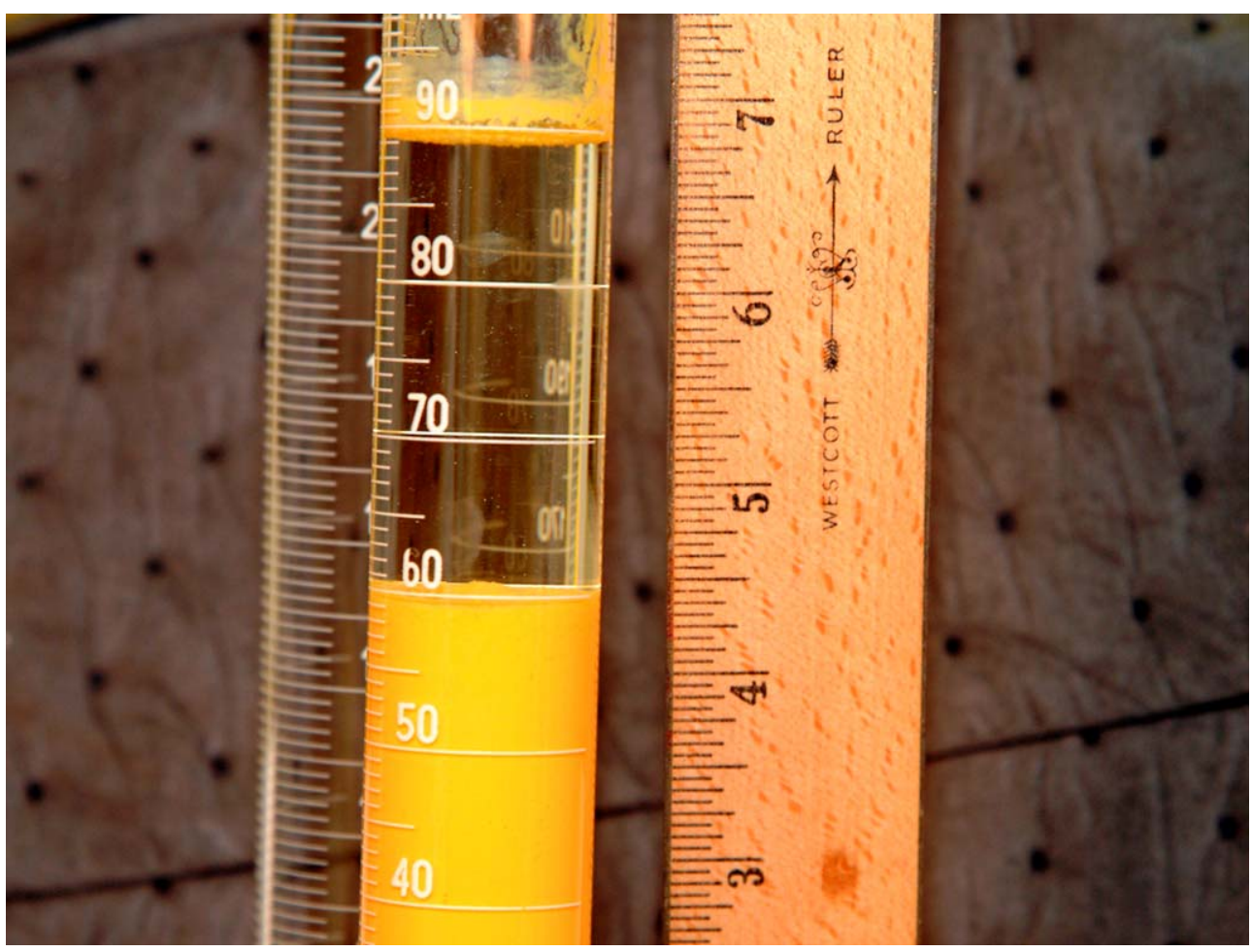

Figure 7 - Graduated Cylinder Settling Test

\subsubsection{Heating test in water bath}

Personnel placed samples in capped polypropylene bottles and placed these in a $50{ }^{\circ} \mathrm{C}$ water bath to simulate the high temperature storage conditions. We removed samples as necessary and tested through the race track to determine the impact of temperature on flowrate. No attempt was made to control the temperature of the slurry after it was removed from the water bath as the transfer piping, like the racetrack, would be at ambient temperature and would quickly cool the slurry.

\subsubsection{Other tests and analyses}

We performed a number of other analyses on samples in an attempt to understand the poor flow behavior. Table 6 summarizes these measurements. 
WSRC-TR-2002-00569, REV. 0

Table 6 - Additional Testing Performed

\begin{tabular}{|c|c|}
\hline Test & Reason for Test \\
\hline Dilution and Concentration & Understand impact of concentration on flow \\
\hline Rheology & Understand flow behavior of slurry \\
\hline Particle Size & Determine range of particle sizes \\
\hline Scanning Electron Microscopy & Visual look at particles and agglomerates \\
\hline Ion Chromatography & $\begin{array}{l}\text { Analyze for impurities from Lab Waste and } \\
\text { nitrate from solution makeup }\end{array}$ \\
\hline Gas Chromatography/MS & \multirow{2}{*}{ Analyze for impurities from Lab Waste } \\
\hline Fourier Transformed Infra Red & \\
\hline Carbon Analyses (TIC/TOC) & $\begin{array}{l}\text { Analyze for impurities from Lab Waste and } \\
\text { Carbonate from } \mathrm{CO}_{2} \text { sorption }\end{array}$ \\
\hline $\begin{array}{c}\text { Inductive Couple Plasma } \\
\text { Spectroscopy ICP-ES, ICP-MS }\end{array}$ & Elemental composition of slurry \\
\hline Titration & Measure free hydroxide and carbonate \\
\hline Solids Measurement & Measure insoluble solids (DU) \\
\hline
\end{tabular}

\subsection{ANALYSIS AND TESTING OF F-CANYON TANKS 13.1 AND 13.3 SAMPLES}

F-Canyon personnel shipped 10 samples (totaling approximately $100 \mathrm{~mL}$ ) of both Tank 13.1 and 13.3 simulant to SRTC for analysis and testing. We analyzed the composited samples from each tank. The data indicates a large difference in insoluble solids concentration between Tank 13.1 and 13.3. Tank 13.1 also contained a much more dilute supernate than Tank 13.3 as indicated by a lower density. Table 7 contains the analytical results while Appendix 8.1 summarizes the detailed analyses.

Table 7 - Summary Analysis of F-Canyon Tank 13.1 and 13.3 Samples

\begin{tabular}{|l|c|c|c|}
\hline \multicolumn{1}{|c|}{ Analysis } & Target & $\begin{array}{c}\text { F-Canyon Simulant } \\
\text { Tank 13.1 }\end{array}$ & $\begin{array}{c}\text { F-Canyon Simulant } \\
\text { Tank 13.3 }\end{array}$ \\
\hline Depleted Uranium, g/L & 33 & 24.5 & 46.2 \\
\hline Insoluble Solids, wt \% & 3.15 & 0.43 & 2.68 \\
\hline Supernate Density, g/mL & 1.11 & 1.09 & 1.11 \\
\hline Slurry Density, g/mL & 1.13 & 1.09 & 1.14 \\
\hline
\end{tabular}

As a result of these analyses, F-Canyon personnel decided to combine the contents of Tanks 13.1 and 13.3 and redistribute the contents between the two tanks. F-Area's C-Lab analyzed samples from these two tanks to determine whether they were acceptable for the simulant test.

Table 8 compares F Canyon Simulants. 
WSRC-TR-2002-00569, REV. 0

Table 8 - Comparison of F-Canyon Simulants

\begin{tabular}{|l|c|c|c|}
\hline Analysis & $\begin{array}{c}\text { F-Canyon Simulant } \\
\text { Poor Flow }\end{array}$ & $\begin{array}{c}\text { F-Canyon Simulant } \\
\text { Tank 13.1 }\end{array}$ & $\begin{array}{c}\text { F-Canyon Simulant } \\
\text { Tank 13.3 }\end{array}$ \\
\hline Settling Rate & $\begin{array}{c}27 \% \text { settled in } 30 \\
\text { min }\end{array}$ & $\begin{array}{c}85 \% \text { settled in 30 } \\
\text { min }\end{array}$ & $70 \%$ settled in 30 min \\
\hline $\begin{array}{l}\text { Settling Volume of } \\
\text { solids }\end{array}$ & $66 \%$ & $7.5 \%$ & $14 \%$ \\
\hline $\begin{array}{l}\text { Mean Particle Size, } \\
\text { um }\end{array}$ & $21.4^{*}$ & 6.8 & 9.9 \\
\hline $\begin{array}{l}\text { Racetrack Flow } \\
\text { time, sec }\end{array}$ & 120 & 7.1 & 7.3 \\
\hline $\begin{array}{l}\text { DU Concentration, } \\
\text { g/mL }\end{array}$ & 41.5 & 24.5 & 46.2 \\
\hline
\end{tabular}

\subsection{RESULTS}

The following sections discuss the impact of the various variables on the flow behavior of the simulated waste. In this discussion a number of simulants will be discussed. The list below describes the various simulants. More information is available in appendix 8.2.

- $\quad$ SRTC Simulant - Fast Caustic Addition - Simulant prepared by combining DU and nitric acid and quickly adding caustic (several minute addition)

- $\quad$ SRTC Simulant - Slow Caustic Addition - Simulant prepared by combining DU and nitric acid and slowly adding caustic ( 2 hour addition)

- SRTC Complete Simulant - Simulant prepared with Am/Cm Simulant and DU

- SRTC Simulant - Iron Substituted for Depleted Uranium - Simulant prepared by combining Fe and nitric acid and slowly adding caustic

- F-Canyon Simulant - Poor Flow - Sample of poor flowing simulant shipped from FCanyon

- F-Canyon Simulant - Tank 13.1 - Sample of $2^{\text {nd }}$ batch of F-Canyon Simulant (Tank 13.1)

- F-Canyon Simulant - Tank 13.3- Sample of $2^{\text {nd }}$ batch of F-Canyon Simulant (Tank 13.1)

\subsubsection{Shearing particles lowers particle size}

Blender testing examined the impact of shear on particle size and flowrate. We performed two tests, one using the SRTC Simulant - Fast Caustic Addition and the SRTC Complete Simulant. In addition, we submitted samples for particle size analysis (Microtrac ${ }^{\circledR}$ particle size analyzer). Figure 8 contains that data. Note that although particle size decreased due to the agitation shear, we observed no appreciable change in flowrate.

We also used agitator testing to determine the impact of agitation shear on flowrate using the SRTC Complete Simulant. No change was observed yet in flow times through the racetrack. Limited periods of agitation do not significantly alter flow behavior.

\footnotetext{
* Based on SEM pictures, the particles are very small but have agglomerated. This is the size of the agglomerated particles.
} 
WSRC-TR-2002-00569, REV. 0

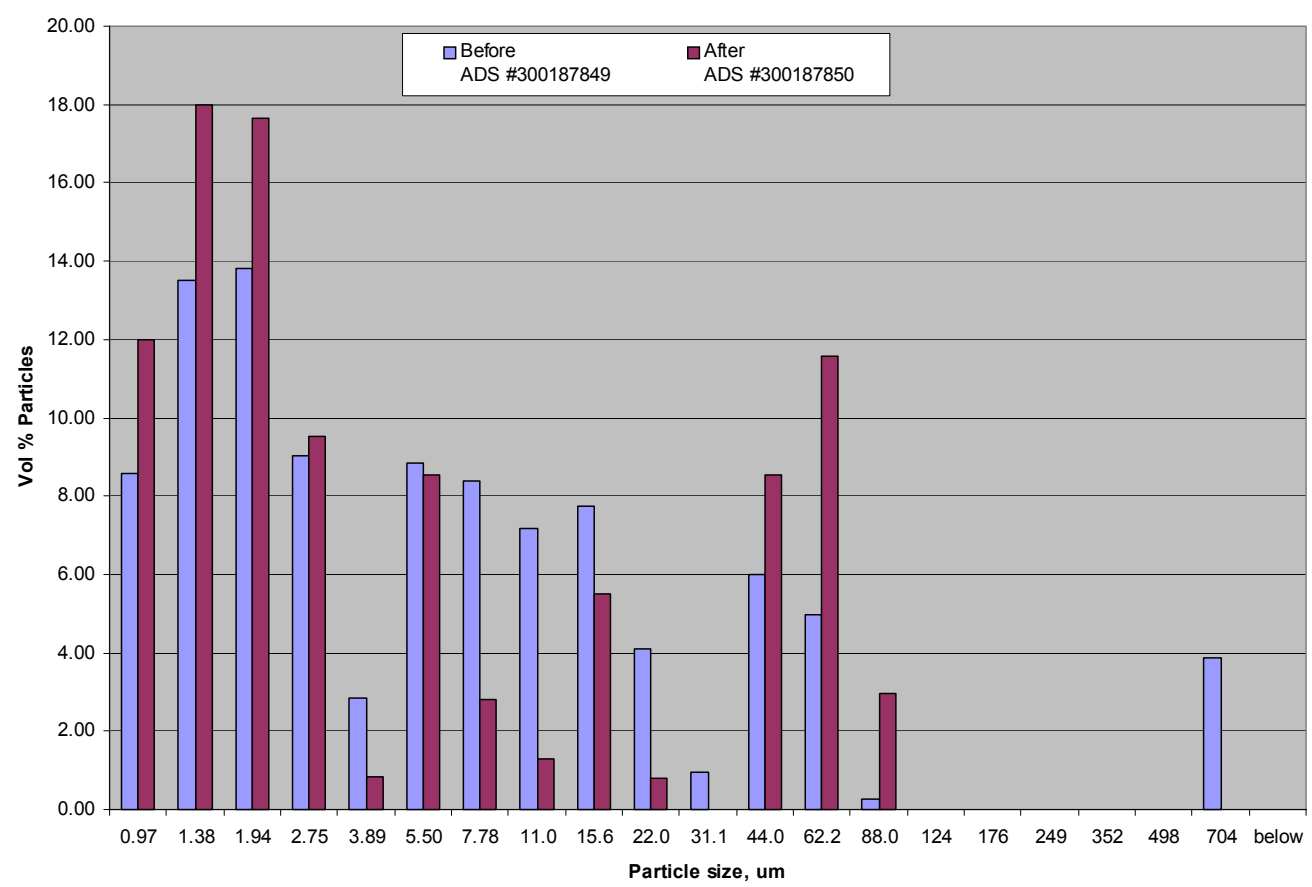

Figure 8 - Particle Size Before and After Shearing in Waring ${ }^{\circledR}$ Blender

\subsubsection{Heating changes particles}

Testing examined whether the storage of the simulant in Tank 13.3 at $50{ }^{\circ} \mathrm{C}$ impacted the crystals and particle-particle interactions, independent of a change in concentration. Figure 9 shows the data.

Temperature did have a significant impact on flowrate for some of the tested simulants. We observed no perceptible change for the SRTC Complete Simulant. The flow time for the SRTC Simulant - Slow Caustic Addition increased approximately 3x during approximately three weeks at $50{ }^{\circ} \mathrm{C}$, as measured through the race track. This change in flow behavior does not correlate with a concentration change since we stored samples in capped sample bottles. We weighed sample bottles before and after storage to measure evaporative losses. During two weeks of testing, the sample loss was $<0.3 \mathrm{wt} \%$. 
WSRC-TR-2002-00569, REV. 0

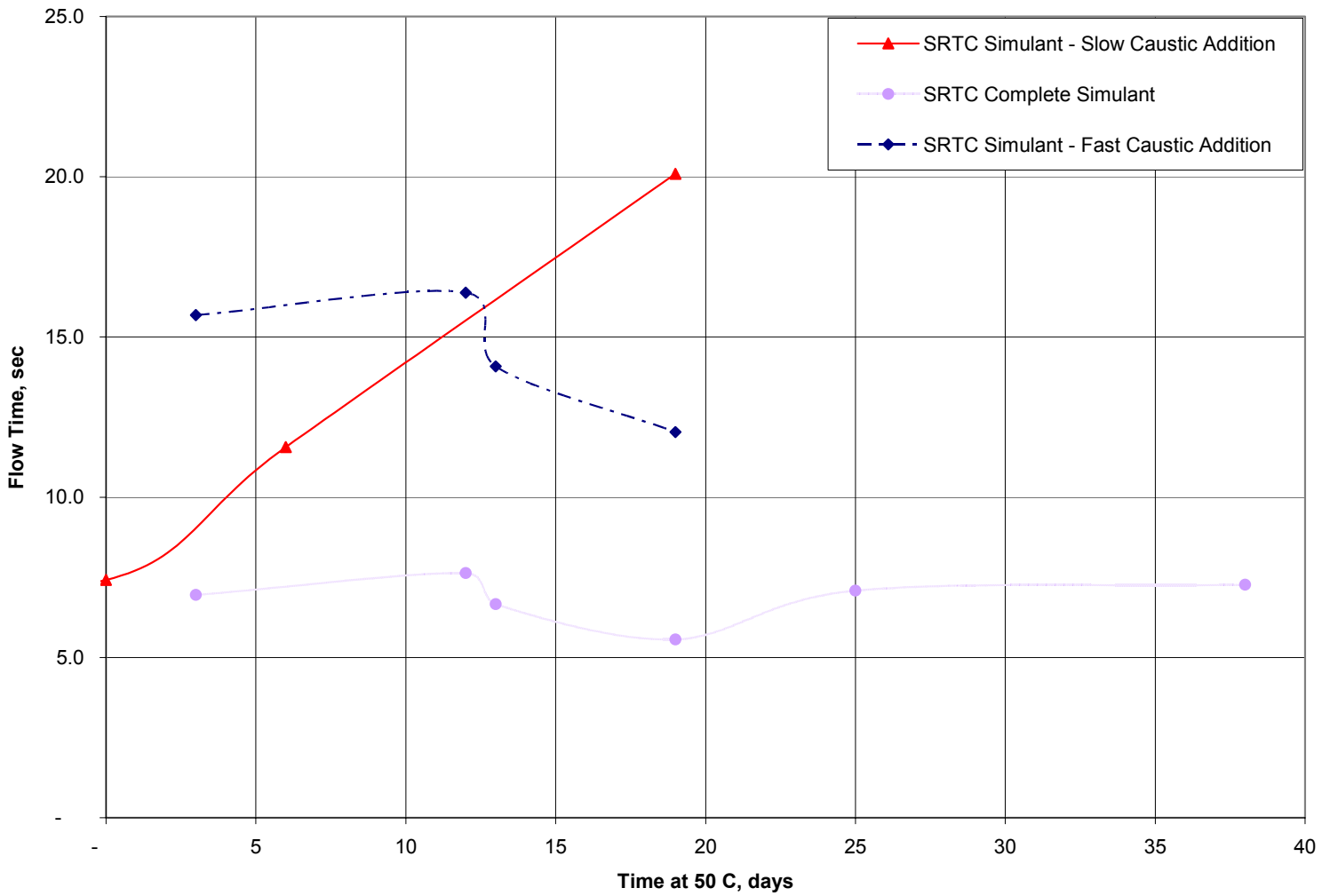

Figure 9 - Testing of Simulants stored at $50^{\circ} \mathrm{C}$

\subsubsection{Concentration changes rheology}

Initial testing with the F-Canyon Simulant - Poor Flow demonstrated that it took approximately 10 times longer to flow through the race track than the fresh simulants prepared by SRTC. Program management elected to discard the remaining simulant and asked SRTC to determine whether dilution would allow transfer through the gravity drain line. We performed a dilution study starting with $15 \mathrm{~mL}$ of the F-Canyon Simulant - Poor Flow. We added water incrementally and measured the race track flow time results summarized in Table 9. 
Table 9 - Dilution Study with F-Canyon Simulant - Poor Flow

\begin{tabular}{|c|c|c|c|c|}
\hline Added water, $\mathrm{mL}$ & \%added water & wt \% solids & Flowrate, $\mathrm{ft} / \mathrm{s}$ & Flow, $\mathrm{s}$ \\
\hline 0 & 0.0 & $4.21 \%$ & 0.011 & 89.8 \\
\hline 1 & 6.7 & $3.97 \%$ & 0.017 & 59.9 \\
\hline 2 & 13.3 & $3.76 \%$ & 0.025 & 40.0 \\
\hline 3 & 20.0 & $3.58 \%$ & 0.033 & 30.7 \\
\hline 4 & 26.7 & $3.40 \%$ & 0.044 & 23.0 \\
\hline 5 & 33.3 & $3.25 \%$ & 0.057 & 17.7 \\
\hline 6 & 40.0 & $3.11 \%$ & 0.065 & 15.5 \\
\hline 7 & 46.7 & $2.98 \%$ & 0.065 & 15.5 \\
\hline 8 & 53.3 & $2.86 \%$ & 0.077 & 13.0 \\
\hline 9 & 60.0 & $2.75 \%$ & 0.083 & 12.1 \\
\hline 10 & 66.7 & $2.65 \%$ & 0.089 & 11.3 \\
\hline 11 & 73.3 & $2.55 \%$ & 0.096 & 10.5 \\
\hline 12 & 80.0 & $2.47 \%$ & 0.098 & 10.3 \\
\hline 13 & 86.7 & $2.38 \%$ & 0.101 & 10.0 \\
\hline 14 & 93.3 & $2.31 \%$ & 0.105 & 9.6 \\
\hline 15 & 100.0 & $2.23 \%$ & 0.107 & 9.4 \\
\hline
\end{tabular}

Based on this testing, personnel added inhibited water (64\% additional volume) to the FCanyon simulant and successfully pumped the slurry through Waste Header 3, through Pump Tank 2 and to Tank 26F.

Analysis of the F-Canyon Simulant - Poor Flow demonstrated that it contained more solids than planned. The DU concentration equaled $44 \mathrm{~g} / \mathrm{mL}$, approximately $33 \%$ higher than planned. We concentrated several simulants and examined the flow rates as a function of solids content. Testing used evaporation, then supernate removal to reach the higher concentrations. Figure 10 contains the results.

The testing shows that as the insoluble solids concentration increases, the time to flow through the race track increases. The SRTC Simulant - Slow Caustic Addition exhibited very similar flow behavior to the F-Canyon Simulant - Poor Flow. However, the SRTC Complete Simulant and Tank 13.3 Simulant can both be concentrated to much higher insoluble solids concentration before significant reduction in flow rate occurs. Hence, insoluble solids concentration significantly impacts the flow time through the race track because of the rheology of the simulant. 
WSRC-TR-2002-00569, REV. 0

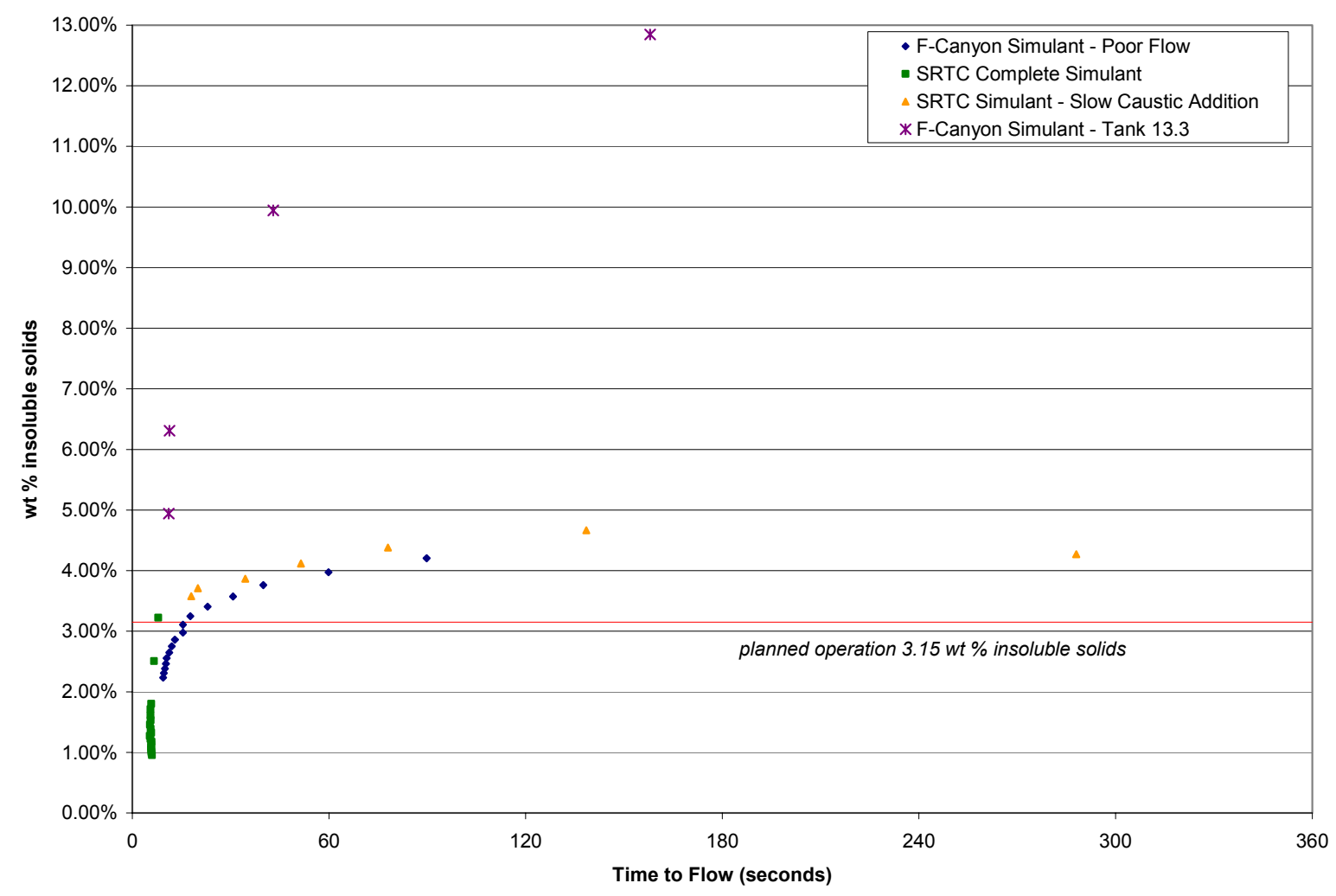

Figure 10 - Concentration Study of Various Simulants

\subsubsection{Do chemical additives change rheology?}

We added three chemical additives to the SRTC Simulant - Slow Caustic Addition samples. We selected these chemicals because they represent components present in the lab waste, as determined by analysis of the Tank 13.3 material, and speculated as likely candidates to impact slurry rheology. Note that only the addition of tri-n-butyl phosphate (TBP) decreased the flowrate as measured in the race track when compared to the behavior of SRTC Simulant - Slow Caustic Addition without additives.

\subsubsection{Carbonate sorption}

The strong caustic solution ( $>1 \mathrm{M}$ free hydroxide) readily sorbs carbon dioxide from air; air contains $\sim 0.03$ vol $\% \mathrm{CO}_{2}$. Tank 13.1 and 13.3 operating conditions included a purge with 4 scfm (1.5 required) air for the duration of the storage. The tank agitator likely produces a vortex which increases the air contact with the slurry. Analysis of the F-Canyon Simulant Poor Flow, by the Total Inorganic Carbon method, indicated $0.3 \mathrm{M}$ carbonate in solution. We added 0.3 M sodium carbonate to the SRTC Simulant - Slow Caustic Addition and periodically tested this material using the racetrack. Figure 11 shows that carbonate actually improved the flowrate through the racetrack. 
WSRC-TR-2002-00569, REV. 0

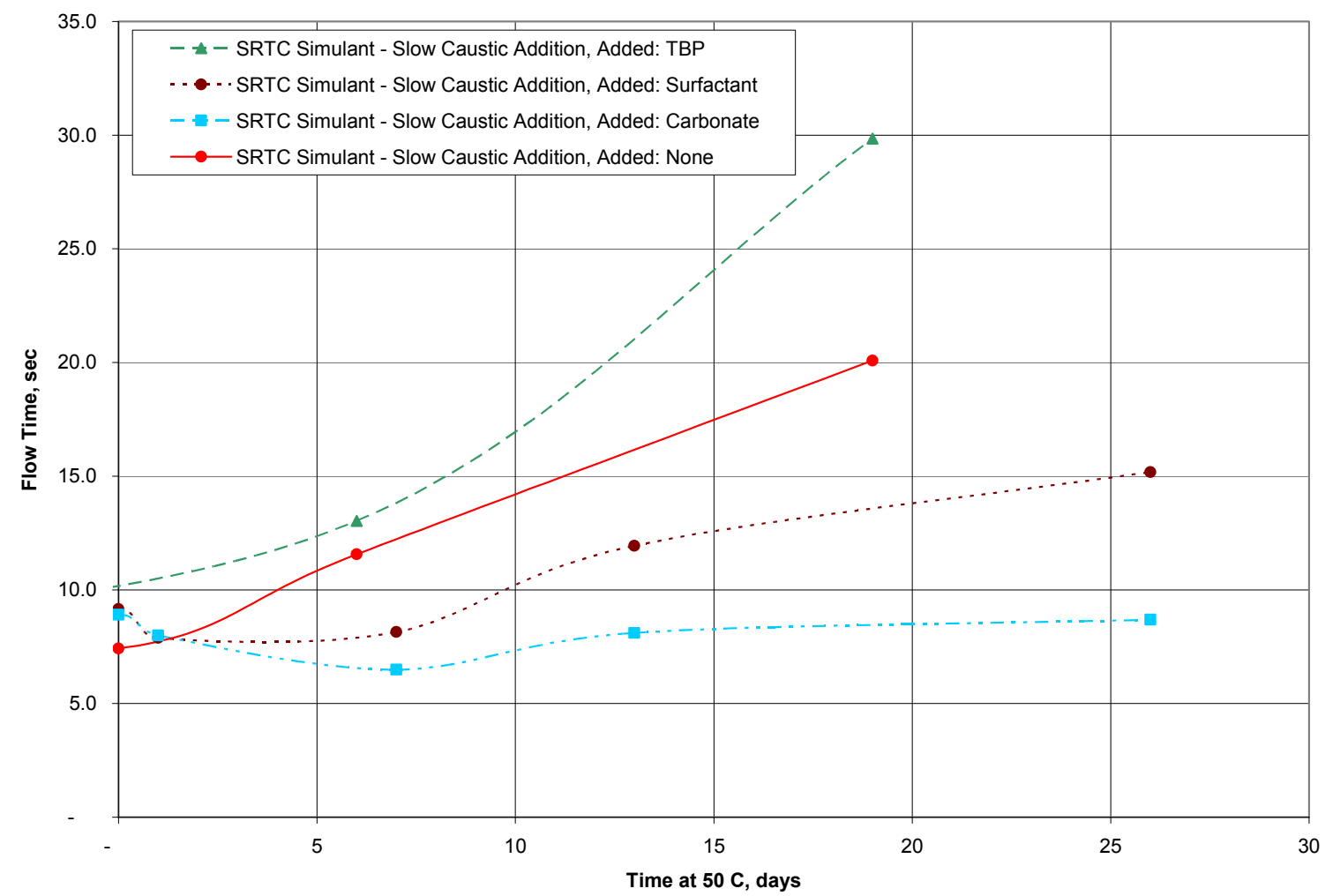

Figure 11 - Racetrack testing of Simulants with added carbonate, TBP and surfactant

\subsubsection{Tri-n-butyl phosphate}

The F-Canyon Simulant - Poor Flow contained $61 \mathrm{mg} / \mathrm{kg}$ phosphate as measured by Ion Chromatography anion analysis. If all the phosphate came from tributylphosphate (TBP), $667 \mathrm{mg} / \mathrm{kg}$ TBP is present in the F-Canyon Simulant - Poor Flow. We added $667 \mathrm{mg} / \mathrm{kg}$ TBP to the SRTC Simulant - Slow Caustic Addition and periodically tested the material using the racetrack. Figure 11 depicts a significant increase in flow time after storage of the simulant in the $50{ }^{\circ} \mathrm{C}$ water bath. However, analyses did not explicitly identify TBP present in the F-Canyon Simulant - Poor Flow.. Hence, this variable may not contribute to the observed behavior in F-Canyon operations.

\subsubsection{Did poor mixing during transfer lead to increase $D U$ concentration in later batches?}

Since concentration of the slurry leads to lower flowrate, personnel should avoid any process step that increases the insoluble solids concentration. After F-Canyon prepared new simulant for transfer in November, Tanks 13.1 and 13.3 contained significantly different insoluble concentrations. The acid heel in Tank 13.1 contributed, in part, to this difference. However, the potential also exists that the tanks transfer jet from Tank 13.3 to Tank 13.1 does not pull a representative sample of the slurry. Facility personnel reported that the jet appears to use more steam - and impart more dilution - than typical. Inadequate mixing in Tank 13.1 or 13.3 could contribute to this problem. 


\subsubsection{Did precipitation conditions impact flow?}

A number of variables impact the precipitate crystal size and the kinetics of the precipitation reaction that occurs in preparing the $\mathrm{Am} / \mathrm{Cm}$ material - and simulant - for transfer. Out testing explicitly examined the influence of caustic addition rate on the particle size.

\subsubsection{Caustic addition rate}

We prepared slurries at two caustic addition rates. During initial preparation of simulated slurries, we added the caustic as fast as feasible, over approximately five minutes. We adopted the title SRTC Simulant - Fast Caustic Addition for this material. Later discussions with F-Canyon Engineers indicated that the caustic addition required approximately 2.5 hours for each of the six original batches prepared in Tank 15.4. We prepared additional slurry, identified as SRTC Simulant - Slow Caustic Addition - by adding the caustic over 2.5 hours. We analyzed samples of each for particle size.

A comparison of the SRTC Simulant - Fast Caustic addition to the SRTC Simulant - Slow Caustic Addition indicates smaller particles form with slower addition of the caustic. Scanning Electron Microscopy (SEM) photographs (Figure 12) and particle size analyses (Figure 13) demonstrate this difference.
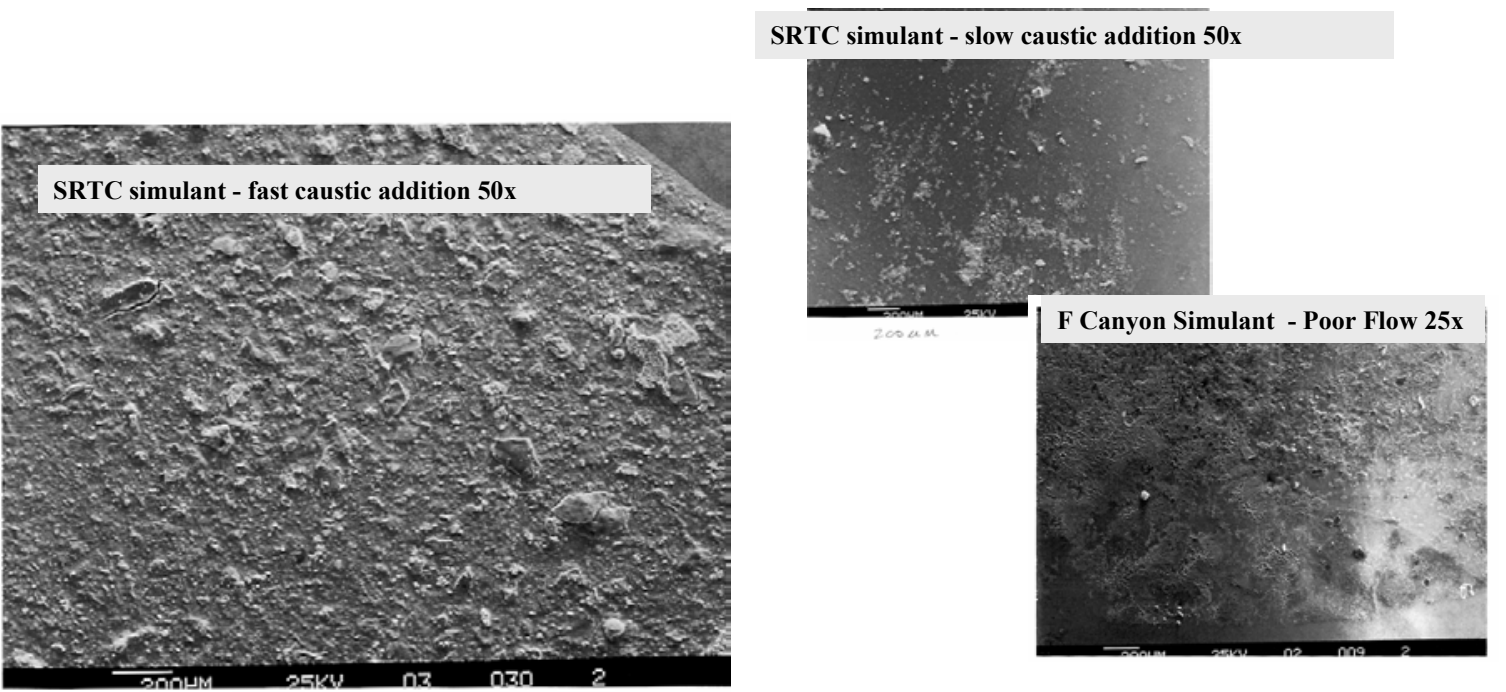

Figure 12 Comparison of SEM Photographs of Slow and Fast Caustic Addition

These findings coupled with any evidence of particle size reduction during our shearing test imply that the small particle size in the F-Canyon Simulant - Poor Flow likely reflect the precipitation conditions (slow caustic addition) and not the shear from the agitator. In addition, smaller particles lead to more surface area per unit volume, which leads to more particle-particle interactions. These smaller particles can lead to peptization, a the thickening of a slurry during agitation. 
WSRC-TR-2002-00569, REV. 0

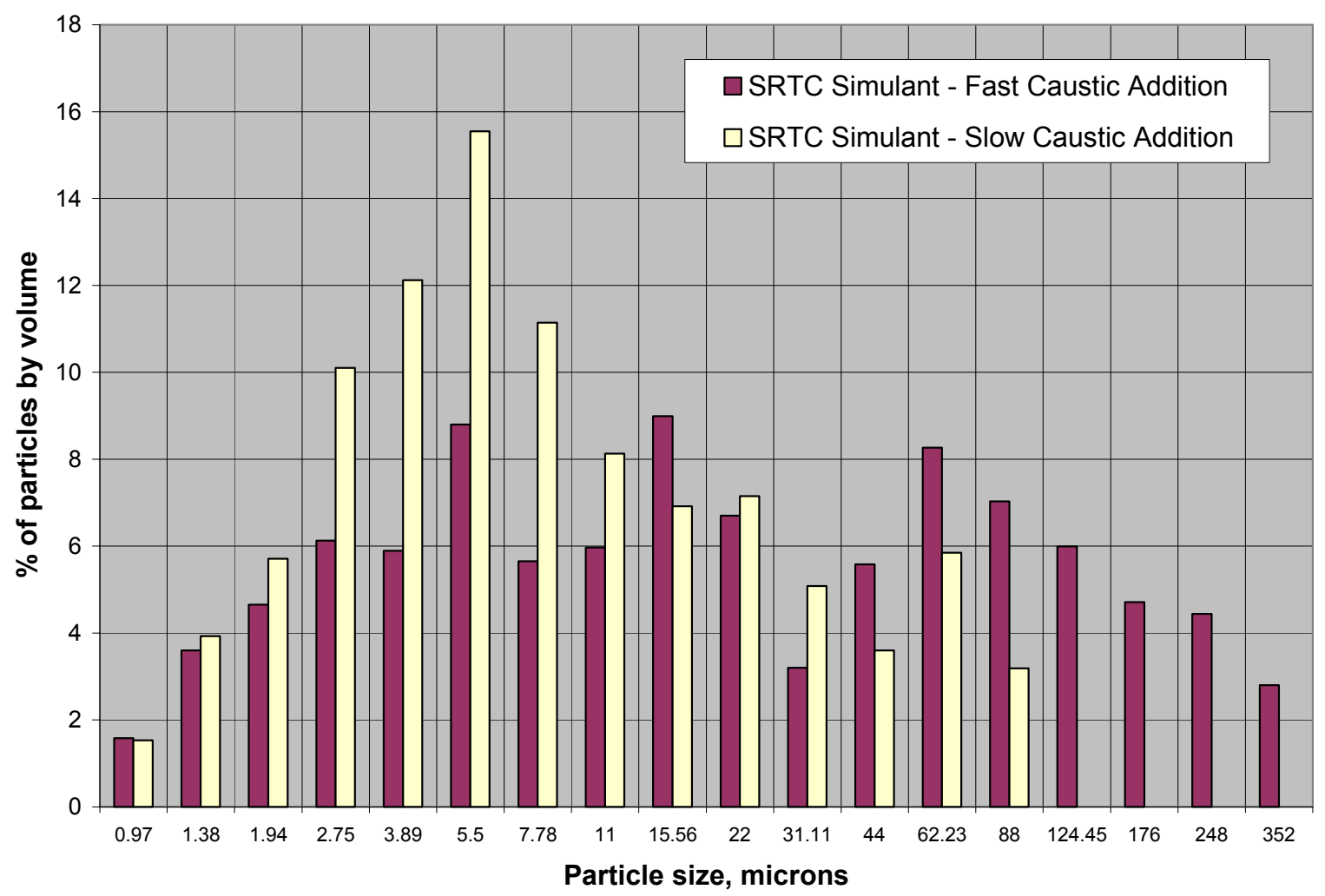

Figure 13 - Particle Size Distribution Comparison - Fast versus Slow Caustic Addition

\subsubsection{How did compositional changes impact flow rate?}

The variations in chemical composition for the simulants led to variations in flow characteristics. For example, we could concentrate the SRTC Complete Simulant to notably higher solids content than the SRTC Complete Simulant - Slow Caustic Addition before adversely impacting the flowrate through the race track (Figure 14).

The SRTC Complete Simulant includes other oxides than just DU as approximately $10 \%$ of the insoluble solids, with iron as the main ingredient. As a result, the crystals formed are not pure uranium oxides.

The SRTC Complete Simulant more rigorously approximates the chemical composition of the actual waste. Hence, the actual waste will likely exhibit less particle-particle interactions and better flow behavior than these simulated slurries. We conducted analogous flow tests with actual waste prepared remaining from the earlier studies by Peters et al. ${ }^{5}$ After $\sim 1$ year of storage, the actual waste suspends easily and flows rapidly through the racetrack. The SRTC Am/Cm Actual Waste 2001 took 10 seconds to run through the racetrack (when tested in 2002), which is comparable to the SRTC Complete Simulant racetrack test. No dilution or concentration testing was completed with actual waste. 
WSRC-TR-2002-00569, REV. 0

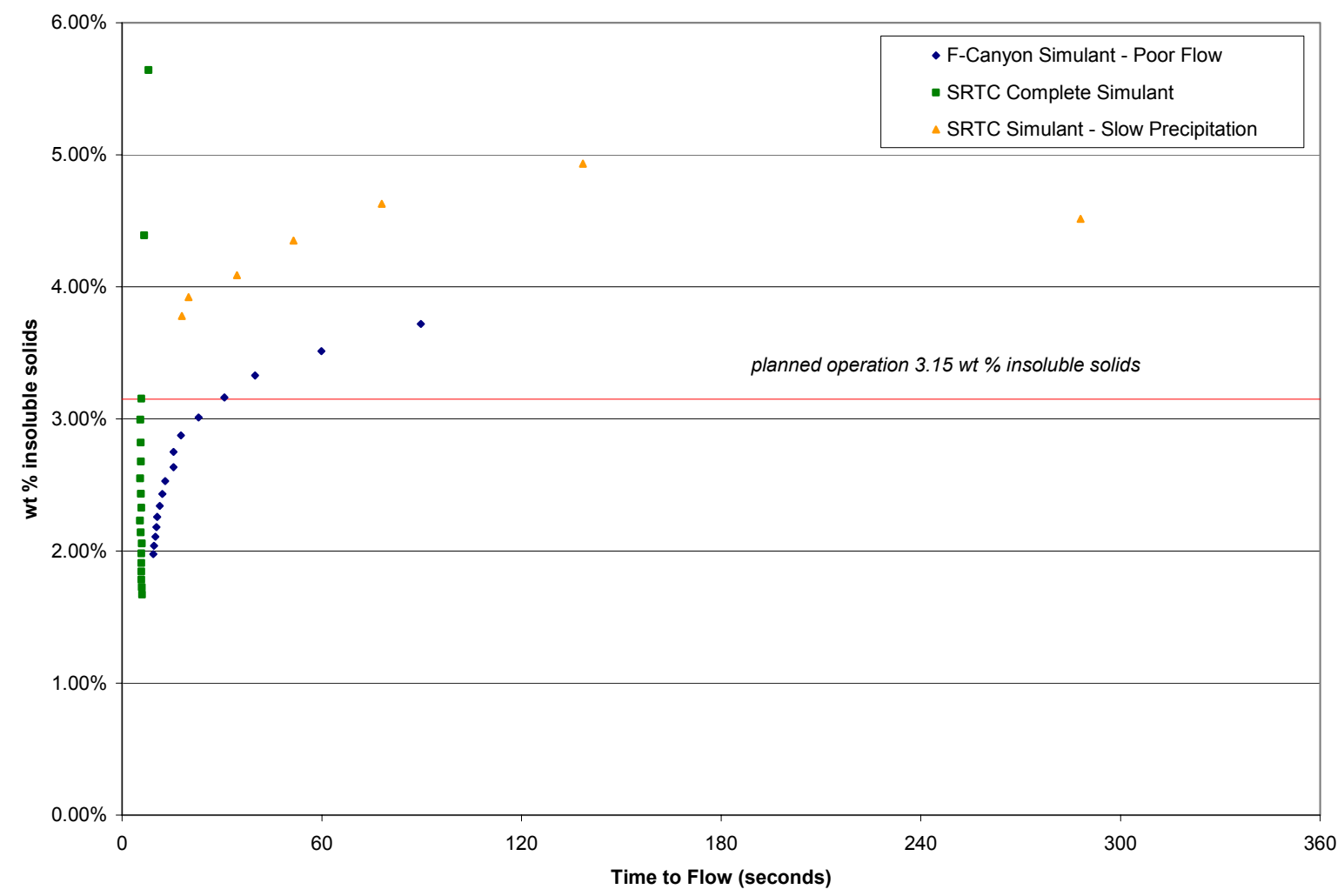

Figure 14 - Concentration study of SRTC Complete Simulant versus F-Canyon Simulant - Poor Flow

\subsubsection{Did solids settling increase frictional losses?}

Transfer by gravity, due to its low flow rate, is susceptible to settling of solids. As solids settle, they increase frictional losses, which decreases flow rate. As the flowrate decreases, more solids settle as the slurry residence time in the transfer line increases. Solids will especially expected to accumulate in elbows and other flow obstructions where frictional losses increase and velocities near the pipe walls decrease. The simulant is fast settling so is more likely to cause this than sludge.

The transfer time between F-Canyon and F Pump Pit Tank 2 is approximately 40 minutes at a flow rate of $30 \mathrm{gpm}$. The average flowrate was $32.5 \mathrm{gpm}$ for the simulant and approximately $40 \mathrm{gpm}$ for most of the real waste transfer. The settling of various slurries is summarized in Figure 15. The actual waste, prepared in 2001 and tested in 2002, was the fastest settling of the slurries tested. As a result of the long transfer time and the potential for quick settling slurries, it was recommended to flush the piping as needed. 
WSRC-TR-2002-00569, REV. 0

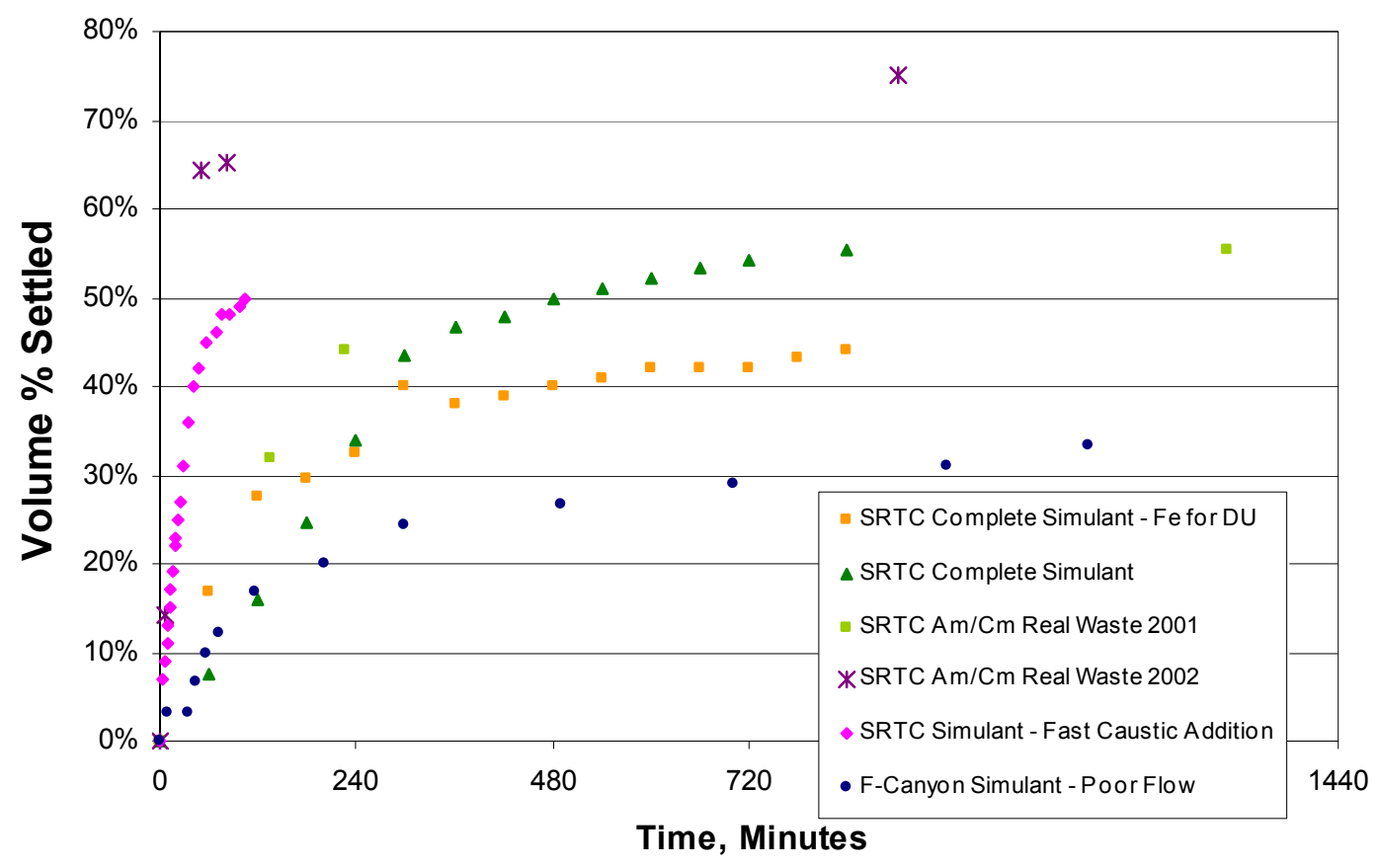

Figure 15 - Settling Graph for Various Slurries 


\subsection{CONCLUSION}

Experimental demonstration and analyses identified the high concentration of insoluble solids in the F-Canyon Simulant - Poor Flow as the primary cause for the poor flow rates achieved during the transfers. The insoluble solids concentration measured approximately $33 \%$ higher than targeted $(33 \mathrm{~g} / \mathrm{L})$ and $47 \%$ higher than the nominal DU concentration planned $(30 \mathrm{~g} / \mathrm{L})$ due to inadvertent evaporation. Keeping the concentration near target will minimize flow problems due to concentration. The small solids produced during precipitation also increase particle-particle interactions which contributes to a rheology change in concentrated solutions. The facility should avoid concentration of the solids to maximize the flow rate of the simulant and actual waste.

The elevated temperature during storage of the F-Canyon Simulant - Poor Flow in Tank 13.3 also contributed to the poor flow rates. This was not exclusively due to concentrating the simulant but was also due to changes resulting from the high temperature storage. F-Canyon personnel installed cooling capability in Tank 13.3 to mitigate and evaporative losses from the slurries. However, the $\mathrm{Am} / \mathrm{Cm}$ waste generates significant heat, approximately 2 watts per gallon, so personnel will need to carefully monitor and control tank temperature, especially while agitating. Personnel need to replace evaporative losses with inhibited water to maintain the concentration in the feed tanks at or below the insoluble solids concentration target.

Some solids settling will occur due to the quick settling solids, the long transfer path and the slow flow rate through the gravity drain lines. As a result, personnel should include the capability for flushing the transfer lines during the transfer as necessary. F-Canyon plans to drain the drain lines prior to performing an inhibited water flush to maximize the effectiveness of line flushing during transfer and will flush the line at the completion of the transfer. Maintaining a maximum velocity during transfer will minimize the solids settling. 
WSRC-TR-2002-00569, REV. 0

\subsection{SUMMARY}

This report summarizes the information collected during the investigation into the cause for the low flow rate in F-Canyon testing. SRTC completed testing and performed engineering calculations to answer the questions as requested by F-Canyon Engineering.

1. What short term fix is needed to disposition the slow flowing simulant?

Add at least 50\% additional water to the F-Canyon Simulant - Poor Flow to allow the successful transfer of the simulant to the F Tank Farm.

2. What controls are needed to ensure future transfers are successful?

- The temperature of the contents of the simulant and real waste storage tanks should be controlled during preparation and storage. Temperature control will minimize the inadvertent evaporation of the slurry and minimize any negative impacts of a high storage temperature. Note that cooling capability has been added to Tank 13.3.

- Any evolution that can inadvertently concentrate the solutions should be avoided. Well mixed storage tanks and the proper transfer of a uniform slurry are necessary to ensure no high concentration slurries are produced.

- Minimize the purge rate in the storage tanks after preparation of the simulant and real waste. The purge will lead to a slow evaporation of the slurry. Note that F-Canyon has lowered the purge in Tanks 13.1 and 13.3 from $4 \mathrm{scfm}$ to $1.5 \mathrm{scfm}$.

- Evaporative losses should be replaced by adding inhibited water as needed.

- During the transfer of the simulant solids will settle, we recommend intermittent flushing with inhibited water to help scour the insoluble solids from the transfer piping.

3. Why did the simulant flow poorly?

Experimental demonstration and analyses identified the high concentration of insoluble solids in the F-Canyon Simulant - Poor Flow as the primary cause for the poor flow rates achieved during the transfers. The insoluble solids concentration measured approximately $33 \%$ higher than targeted $(33 \mathrm{~g} / \mathrm{L})$ and $47 \%$ higher than the nominal DU concentration planned $(30 \mathrm{~g} / \mathrm{L})$ due to inadvertent evaporation. Keeping the concentration near target will minimize flow problems due to concentration. The small solids produced during precipitation also increase particle-particle interactions which contributes to a rheology change in concentrated solutions. The facility should avoid concentration of the solids to maximize the flow rate of the simulant and actual waste.

4. Complete testing to duplicate the poor flow

Testing was completed using an SRTC produced simulant (SRTC Simulant - Slow Caustic Addition) that duplicated the poor flow behavior of the F Canyon Simulant Poor Flow through the removal of supernate from the slurry to concentrate. The measured flow time of the SRTC Simulant - Slow Caustic Addition through the race 
track test were approximately equal to the flow time of the F-Canyon Simulant - Poor Flow in testing at equal insoluble solids concentration. The results are summarized in Figure 10. 
WSRC-TR-2002-00569, REV. 0

\subsection{ACKNOWLEDGEMENTS}

The authors graciously acknowledge the many researchers and technicians in SRTC that assisted in the completion of this task. Various WPT researchers and technicians completed most of the work scope. Calvin Cooks supplied the technicians as needed and his support is appreciated. Lin Thacker, David Healy, Betty Croy, Mona Blume, Sammie McDuffie, Adrienne Williams, Shirley McCollum, and Mike Lee supported us by ably completing the majority of the laboratory work. We had excellent support from Jeff Siler in photographing and videotaping our equipment and tests and editing our photos and videos for maximum clarity. We appreciate the long hours and hard work they performed.

We had great support from Gary Dobos of the glass shop in expediting the fabrication of "racetracks" for us and C-Lab. Researchers and technicians in ADS completed the majority of the analyses. Don Blankenship, Steve Crump, Chuck Coleman, Amy Ekechukwu, Frank Pennebaker, Mike Summer, Mike, Whitaker, Robert Ray, and Bob Hochel together with their technicians supported us by completing over 100 analyses to support this task. In addition Fernando Fondeur complete FT-IR analyses to try to determine the source of the lab waste impurities in the F-Canyon Simulant. Jane Howard and Sherry Vissage, in support of ITS researchers Terri Fellinger, Dave Koopman and Erich Hansen, completed the rheology analyses. We also had support from Michael Poirier in completing calculations to understand the particle settling and Si-Young Lee in modeling the flow transfer to understand the impact of solids and flow rate on our ability to transfer these slurries.

Our customers proved extremely helpful in supporting SRTC during this task. The authors appreciate the support of Ken Parkinson, Paul Peebles, Tom Campbell, Gary Siler, and Julius Lacerna in supplying information, direction and samples to support our investigation. The communication of all the engineers in F-Canyon and HLW proved essential in completing our testing with such a tight time constraint to support the transfer schedule.

The authors thank their managers, particularly Sam Fink and Lou Papouchado for their help in planning, scheduling and communicating the data to the customer as requested. 


\subsection{APPENDIXES}

8.1 ADS ANALYTICAL RESULTS SUMMARY TABLE

8.2 SIMULANT RECIPES

8.3 MISCELLANEOUS DATA

8.4 INTERNAL REPORTS 
WSRC-TR-2002-00569, REV. 0

\subsection{ADS ANALYTICAL RESULTS SUMMARY TABLE}

Table B1 - Analytical Results Summary

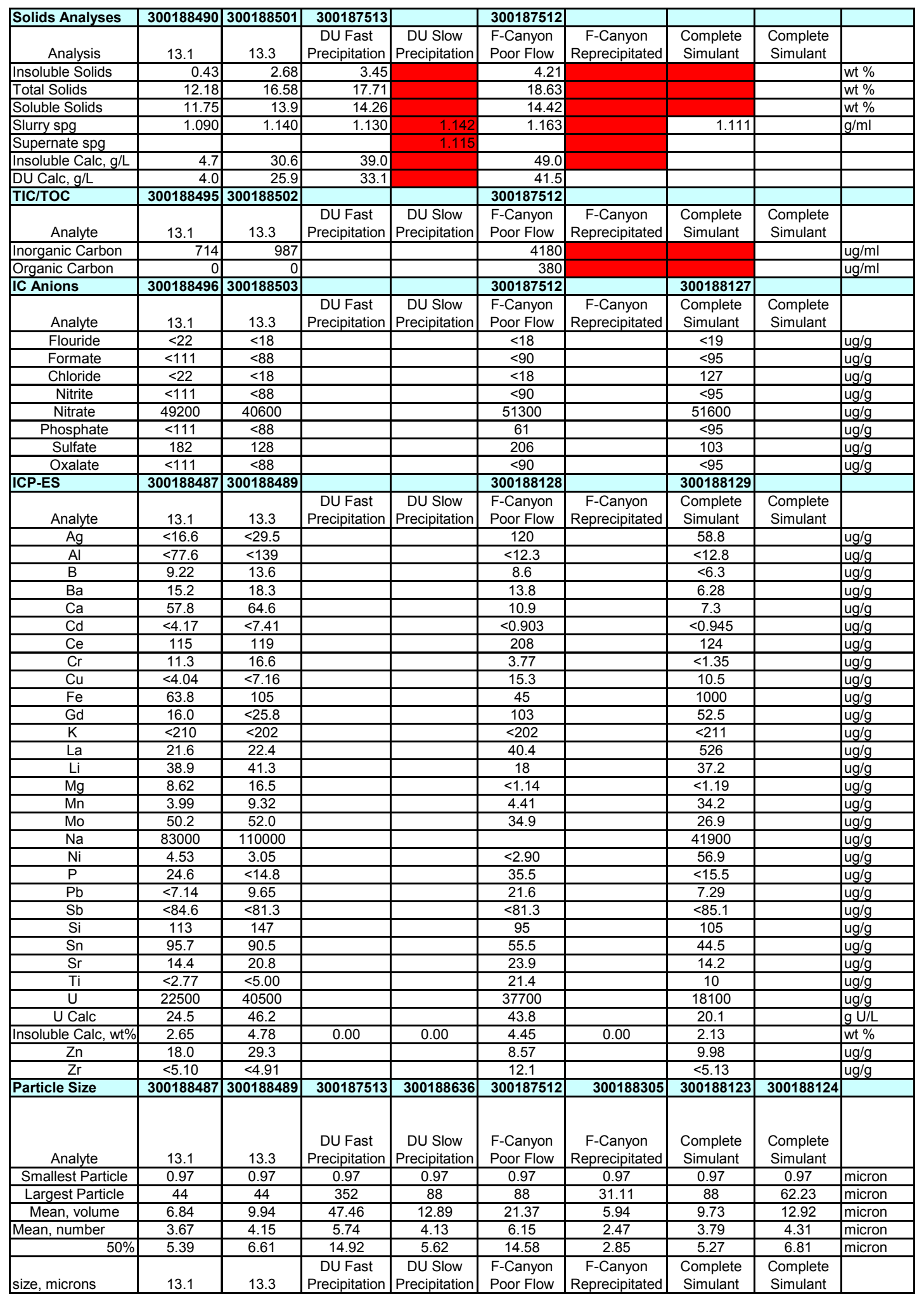




\subsection{SIMULANT RECIPES}

Personnel prepared the following simulants during this testing. They used the Tank 17.1 simulant was combined with DU, caustic and water to prepare the SRTC Complete Simulant and with iron nitrate, caustic and water to prepare the SRTC Simulant - Iron Substituted for DU. The lab notebook summarizes the makeup of these recipes ${ }^{22}$. The following tables summarize the recipes for these simulants.

\subsubsection{Tank 17.1 Simulant}

\begin{tabular}{|l|c|}
\hline Material & amount needed (1L) \\
\hline $\mathrm{Al}\left(\mathrm{NO}_{3}\right)_{3} \cdot 9 \mathrm{H}_{2} \mathrm{O}$ & $25.5 \mathrm{~g}$ \\
\hline $\mathrm{Fe}\left(\mathrm{NO}_{3}\right)_{3} \cdot 9 \mathrm{H}_{2} \mathrm{O}$ & $76.0 \mathrm{~g}$ \\
\hline $\mathrm{La}\left(\mathrm{NO}_{3}\right)_{3} \cdot 6 \mathrm{H}_{2} \mathrm{O}$ & $16.9 \mathrm{~g}$ \\
\hline $\mathrm{LiOH}$ & $1.51 \mathrm{~g}$ \\
\hline $\mathrm{Mn}\left(\mathrm{NO}_{3}\right)_{2}$ & $\begin{array}{c}1.55 \mathrm{~mL} \text { (material came } \\
\text { as a } 50 \mathrm{wt} \% \text { solution })\end{array}$ \\
\hline $\mathrm{NaNO}_{3}$ & $6.21 \mathrm{~g}$ \\
\hline $\mathrm{Ni}_{3}\left(\mathrm{NO}_{3}\right)_{2} \cdot 6 \mathrm{H}_{2} \mathrm{O}$ & $3.20 \mathrm{~g}$ \\
\hline $\mathrm{Na}_{2} \mathrm{SiO}_{3} \cdot 9 \mathrm{H}_{2} \mathrm{O}$ & $12.8 \mathrm{~g}$ \\
\hline $\mathrm{Nitric} \mathrm{acid}$ & $\sim 970 \mathrm{~mL}$ \\
\hline
\end{tabular}

\subsubsection{SRTC Complete Simulant}

\begin{tabular}{|l|c|}
\hline Material & Amount $(2 \mathrm{~L})$ \\
\hline depleted uranium & $210 \mathrm{~mL}(240 \mathrm{~g} / \mathrm{L}$ of DU) \\
\hline Tank 17.1 simulant & $200 \mathrm{~mL}$ \\
\hline $50 \mathrm{wt} \% \mathrm{NaOH}$ & $274 \mathrm{~mL}$ \\
\hline dilution water & $1320 \mathrm{~mL}$ \\
\hline
\end{tabular}

\subsubsection{SRTC Simulant - Fast Caustic Addition}

\begin{tabular}{|l|c|}
\hline Material & Amount $(200 \mathrm{~mL})$ \\
\hline $400 \mathrm{~g} / \mathrm{L} \mathrm{DU}$ & $23.11 \mathrm{~g}$ \\
\hline $70 \% \mathrm{HNO} 3$ & $11.98 \mathrm{~g}$ \\
\hline $50 \% \mathrm{NaOH}$ & $43.29 \mathrm{~g}$ \\
\hline Water & $146.61 \mathrm{~g}$ \\
\hline Total & $225.00 \mathrm{~g}$ \\
\hline
\end{tabular}


WSRC-TR-2002-00569, REV. 0

8.2.4 SRTC Simulant - Slow Caustic Addition

\begin{tabular}{|l|c|}
\hline Material & Amount $(350 \mathrm{~mL})$ \\
\hline $240 \mathrm{~g} / \mathrm{L} \mathrm{DU}$ & $67.70 \mathrm{~g}$ \\
\hline $70 \% \mathrm{HNO}_{3}$ & $21.06 \mathrm{~g}$ \\
\hline $50 \% \mathrm{NaOH}$ & $76.09 \mathrm{~g}$ \\
\hline Water & $230.61 \mathrm{~g}$ \\
\hline Total & $395.47 \mathrm{~g}$ \\
\hline Calculated DU concentration & $34.63 \mathrm{~g} / \mathrm{L}$ \\
\hline
\end{tabular}

\subsubsection{SRTC Simulant - Iron Substituted for Depleted Uranium}

\begin{tabular}{|l|c|}
\hline Material & Amount $(141 \mathrm{~mL})$ \\
\hline $\mathrm{Fe}\left(\mathrm{NO}_{3}\right) 3 \cdot 9 \mathrm{H}_{2} \mathrm{O}$ & $23.7 \mathrm{~g}$ in $9.4 \mathrm{~mL}$ of water \\
\hline Tank $17.1 \mathrm{simulant}$ & $13 \mathrm{~mL}$ \\
\hline $50 \mathrm{wt} \% \mathrm{NaOH}$ & $26.7 \mathrm{~mL}$ \\
\hline dilution water & $91.4 \mathrm{~mL}$ \\
\hline
\end{tabular}




\subsection{MISCELLANEOUS DATA}

\begin{tabular}{|c|c|c|}
\hline \multicolumn{2}{|c|}{ Particle Size Data for the Various Simulants } \\
\hline & \multicolumn{2}{|c|}{$\%$ in Channel } \\
\hline Size (microns) & $\begin{array}{c}\text { F Canyon Simulant } \\
- \text { Poor Flow }\end{array}$ & $\begin{array}{c}\text { SRTC Simulant - Fast } \\
\text { Caustic Addition }\end{array}$ \\
\hline 0.82 & 1.26 & 1.58 \\
\hline 1.16 & 3 & 3.6 \\
\hline 1.64 & 3.85 & 4.65 \\
\hline 2.31 & 4.75 & 6.13 \\
\hline 3.27 & 4.64 & 5.89 \\
\hline 4.62 & 8.8 & 8.8 \\
\hline 6.54 & 8.07 & 5.65 \\
\hline 9.25 & 8.05 & 5.97 \\
\hline 13.08 & 9.67 & 8.99 \\
\hline 18.5 & 10.96 & 6.7 \\
\hline 26.16 & 11.29 & 3.2 \\
\hline 37 & 10.45 & 5.58 \\
\hline 52.33 & 9.47 & 8.27 \\
\hline 74 & 5.74 & 7.03 \\
\hline 104.65 & & 5.99 \\
\hline 148 & & 4.71 \\
\hline 209.3 & & 4.44 \\
\hline 296 & & 2.8 \\
\hline & & \\
\hline & & \\
\hline
\end{tabular}




\begin{tabular}{|c|c|}
\hline & \% in Channel \\
\hline Size (microns) & $\begin{array}{c}\text { SRTC Complete Simulant } \\
- \text { Fe for DU }\end{array}$ \\
\hline 1.375 & 0.92 \\
\hline 1.945 & 1.9 \\
\hline 2.75 & 4.83 \\
\hline 3.889 & 6.86 \\
\hline 5.5 & 8.82 \\
\hline 7.778 & 9.93 \\
\hline 11 & 10.97 \\
\hline 15.56 & 12.7 \\
\hline 22 & 12.51 \\
\hline 31.11 & 10.3 \\
\hline 44 & 9 \\
\hline 62.23 & 6.58 \\
\hline 88 & 3.66 \\
\hline 124.5 & 0.99 \\
\hline 176 & 0.03 \\
\hline
\end{tabular}

\begin{tabular}{|c|c|c|}
\hline & \multicolumn{2}{|c|}{ \% in Channel } \\
\hline & \multicolumn{2}{|c|}{ SRTC Complete Simulant } \\
\hline Size (microns) & Before Shearing & After Shearing \\
\hline 0.97 & 8.28 & 11.98 \\
\hline 1.38 & 12.82 & 17.99 \\
\hline 1.94 & 12.88 & 17.66 \\
\hline 2.75 & 7.36 & 9.51 \\
\hline 3.89 & 2.28 & 0.85 \\
\hline 5.5 & 10.30 & 8.54 \\
\hline 7.78 & 8.39 & 2.81 \\
\hline 11 & 7.09 & 1.30 \\
\hline 15.56 & 8.06 & 5.49 \\
\hline 22 & 5.85 & 0.80 \\
\hline 31.11 & 0.53 & 0.00 \\
\hline 44 & 4.80 & 8.52 \\
\hline 62.23 & 8.10 & 11.59 \\
\hline 88 & 3.25 & 2.97 \\
\hline
\end{tabular}


WSRC-TR-2002-00569, REV. 0

\subsection{INTERNAL REPORTS}

\subsubsection{HLW/SRTC memo recommending the disposal of original simulant}

Westinghouse

Savannah River Company

Aiken, SC 29808

NMM-EST-2002-00174

Retention: 5 yrs

October 25, 2002

To: $\quad$ V. G. Dickert, HLWD

From: M. E. Logan, 221-F

L. M. Papouchado, 773-A

\section{DISPOSITION OF AM/CM SIMULANT MATERIAL}

Simulant material (DU diuranyl nitrate slurry) was prepared for testing the readiness of NMMD and HLWD equipment and personnel to transfer neutralized Am/Cm slurry from NMMD's F-Canyon to HLWD's Tank 51. The simulant material did not flow as expected, and an investigation was performed. Some conclusions can be deduced from the results of the investigation.

\section{Am-Cm Simulant Dilution with Lab Waste}

- During storage of Am-Cm simulant (neutralized depleted uranium (DU), sodium nitrate, and excess caustic) in tank 13.3, loss of volume due to evaporation created a need to dilute the simulant.

- To accomplish a leak check of an Am-Cm piping route (17.1 to 15.4), the decision was made by F-Canyon Operations and Engineering to dilute 13.3 with Lab Waste material from tank 17.2.

- Lab Waste material (tank 809) consists of the following materials

- CLAB high and low level waste 
- $\quad$ SRTC high level waste

- 800 cell sump solution (typically rainwater)

- Lab Waste is routinely batched (1 to 2 times per week) into F-Canyon tank 17.2 where it is sampled.

- The Lab Waste material is forwarded to the Low Activity Waste system where it is combined with other acidic wastes.

- The combined waste is concentrated by evaporation, poisoned by the addition of DU, neutralized with caustic, sampled to ensure WCP compliance, and then sent to HLWD.

- Lab Waste is addressed in a WCP (waste stream FCAN-RW-05).

- A USQ Screening was prepared to evaluate adding Lab Waste material to tank 13.3.

- The USQ concluded addition of Lab Waste would not take 13.3 outside of compliance with its special WCP (waste stream FCAN-SW-08).

- On 8/9/02, about 11,000 pounds of Lab Waste material was transferred from tank 17.2 to tank 15.4, neutralized with caustic, and subsequently transferred to tank 13.3.

- Tank 17.2 analyses indicate the Lab Waste material was typical $(\mathrm{O} / \mathrm{A}=0.034 \%$, alpha $5 \mathrm{E}+5 \mathrm{~d} / \mathrm{m} / \mathrm{ml}$, acidity $0.14 \mathrm{M})$.

- $\quad$ Tank 13.3 also was sampled, and met WCP requirement.

- SRTC evaluation has not identified any unusual constituents that might have caused the observed behavior of the Am-Cm simulant (e.g., no detectable organics).

- SRTC has determined that dilution of the Am-Cm simulant by $>50 \%$ will modify flow characteristics to near normal.

- The Am-Cm simulant in tank 13.1 has been diluted by $64 \%$.

\section{Summary}

- Lab Waste is routinely transferred to HLWD under an approved WCP.

- Depleted uranium is routinely combined with Lab Waste before transfer to HLWD.

- Dilution of the Am-Cm simulant by $>50 \%$ eliminates the flow problems

- The simulant has been diluted by $64 \%$

- Since Lab Waste is a normal waste stream and is routinely combined with DU, there is no reason to believe the Am-Cm simulant will behave differently than normal waste, after transfer to the tank farm.

- The USQ Screening and subsequent sample analyses determined that the addition of Lab Waste material to the Am-Cm simulant was within the bounds of the special WCP (FCAN-SW-08).

- A "Lessons Learned" will be issued committing to improved communication of process changes between NMMD and HLWD. 
SRTC (Dan Lambert, Tom Peters and Mary Stallings) participated with NMMD Engineering (T. Campbell, S. Brown, and K. Parkinson) in the development of this position paper to address disposal of the unusual $\mathrm{Am} / \mathrm{Cm}$ simulant. SRTC concurs with the above assessment.

It is the judgment of NMMD and SRTC that the processing of this simulant material through HLWD evaporators, salt processing facilities, and the Defense Waste Processing Facility will cause no problems outside the realm of normal operations. 
WSRC-TR-2002-00569, REV. 0

\subsubsection{SRTC memo recommending steps to prevent reoccurrence of Low Flow -- SRT- LWP-2002-00116:}

We investigated the best simulant for use in the next transfer tests for the Am/Cm program. The work included a large battery of tests (see page 3 of the handout), studying not only the F-Canyon Simulant - Poor Flow but also three alternative simulants:

SRTC Simulant - Fast Caustic Addition: This material was made to the same general recipe as the F-Canyon material, using just DU to generate solids.

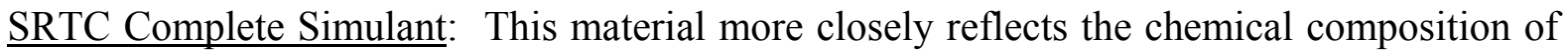
the future $\mathrm{Am} / \mathrm{Cm}$ stream.

SRTC Complete Simulant, Fe for DU: This material was prepared in a similar manner as the "SRTC Complete Simulant", however, we substituted iron on an equal mass basis for the depleted uranium.

Based on the results to date, we recommend the following path forward.

- Our laboratory tests show that precipitated depleted uranium alone, from the canyon, has appropriate flow characteristics (approximately the same as the other SRTC simulants see page 4 of the handout). Furthermore, our tests show that the SRTC Simulant - Fast Caustic Addition settles more quickly than the real waste does, providing a conservative edge (see page 5 of the handout). Finally, there is no distinct advantage to using the other simulants. Hence, we agree with using the SRTC Simulant - Fast Caustic Addition for the transfer test.

- During the transfer of the simulant, we recommend intermittent flushing campaigns. Assuming Newtonian fluid characteristics, it appears that the plant will not meet the minimal flow rates necessary to keep the particles suspended into solution in either the 3" of 10 " pipes (see page 9 of the handout). Hence, settling will occur and periodic flushing will mitigate the obstructions.

- To help prevent a change in the physical characteristics of the freshly precipitated depleted uranium, only a low agitation should be used during the precipitation, and furthermore, adequate cooling should be present to prevent large temperature spikes. When being stored for transfer we recommend that agitation be kept to a minimum, preferably only agitating before the actual transfer. During storage, the temperature of the precipitated material should be kept at ambient. Test results to date only cover ambient material with agitation times of several hours.

- Our initial set of scoping tests shows no adverse affect of increased temperature on the ability of the SRTC Simulant - Fast Caustic Addition to flow. 


\section{BIBLIOGRAPHY}

1 I. M. MacAfee, to P. L. Roggenkamp, "Historical Pu Irradiations", DPST-87-346, March $18,1987$.

2 A. P. Gouge, "Disposition of F-Canyon Am-Cm, Analysis of Disposition Options", NMPESE-940020, Rev. 1, July 13, 1994.

3 C. C. Mason, to W. H. Britton, Letter, "Disposition of Americium (Am) - Curium Solution in the F-Canyon", August 26, 1993.

4 D. A. Berry, "Disposition of Am/Cm Materials Through the High Level Waste System", G-ESR-G-00039, May 1, 2001.

5 T. B. Peters, D. T. Hobbs, D. P. Diprete, C. C. Diprete, and S. D. Fink, "Final Report on the Demonstration of Disposal of Americium and Curium Legacy Material Through the High Level Waste System”, WSRC-TR-2002-00029, January 16, 2002

6 B. A. Davis, "Waste Acceptance Criteria for High Level Liquid Waste Transfers to the 241-F/H Tank Farms," X-SD-G-00001, Rev. 12, July 2001.

7 E. D. Lee, "Waste Pretreatment Facility Waste Acceptance Criteria for Waste Entering the Extended Sludge Processing Tanks 40, 42, and 51", X-SD-H-00001, Rev. 1, November 2000.

8 S. Y. Lee, "Flow Modeling Calculations for Am/Cm Process System, M-CLC-F-00817, October 2002.

9 L. M. Fox, "Flow Calculations from F-Canyon to FPT-2", M-CLC-F-00767, May 2002.

${ }^{10}$ G. W. Govier and K. Aziz, The Flow of Complex Mixtures in Pipes, Malabar: Krieger, 1972, p. 468.

11 A. W. Etchells, "Mixing and Fluid Flow Fundamentals for Defense Waste Processing at Westinghouse Savannah River Corp.”, August 1994.

${ }^{12}$ N. I. Heywood, "Stop Your Slurries from Stirring Up Trouble”, Chem. Eng. Prog., vol. 95, no. 9, pp. 21-41, 1999.

13 I. C. Walton, "Eddy Diffusivity of Solid Particles in a Turbulent Liquid Flow in a Horizontal Pipe", AIChE J., vol. 41, no. 7, pp. 1815-1820, 1995.

14 D. M. Newitt, J. F. Richardson, M. Abbott, and R. B. Turtle, "Hydraulic Conveying of Solids in Horizontal Pipes”, Trans. Instn. Chem. Engrs., vol. 33, pp. 93-110, 1955.

15 W. Parzonka, J. M. Kenchington, and M. E. Charles, "Hydrotransport of Solids in Horizontal Pipes: Effects of Solids Concentration and Particle Size on the Deposit Velocity", Can J Chem Eng, 59, 291 - 296 (1981).

16 T. C. Aude, N. T. Cowper, T. L. Thompson, and E. J. Wasp, "Slurry Piping Systems: Trends, Design Methods, Guidelines", Chemical Engineering, June 28, 1971, pp. 74-90.

${ }^{17}$ Raffi M. Turian and Tran-Fu Yuan, "Flow of Slurries in Pipelines", AIChE Journal, 23, 232-243 (1977).

${ }^{18}$ A. W. Etchells, "Slurry Handling Problems in the Process Industries" in P. Ayazi Shamlou, Ed., Processing of Solid-Liquid Suspensions, Boston: Butterworth-Heinemann, 1993.

${ }^{19}$ C. A. Shook, "Slurry Pipeline Flow", in P. Ayazi Shamlou, Ed., Processing of Solid-Liquid Suspensions, Boston: Butterworth-Heinemann, 1993.

${ }^{20}$ R. M. Turian, F.-L. Hsu, and T.-W. Ma, "Estimation of the Critical Velocity in Pipeline Flow of Slurries", Powder Technology, vol. 51, 1987, pp. 35-47. 
${ }^{21}$ I. C. Walton, "Eddy Diffusivity of Solid Particles in a Turbulent Liquid Flow in a Horizontal Pipe", AIChE Journal, vol 41, 1995, pp. 1815-1820.

22 D. P. Lambert, Am/Cm Flow Investigations, WSRC-NB-2002-00172, October December 2002. 